Board of Governors of the Federal Reserve System

International Finance Discussion Papers

Number 583

June 1997

CAPITAL INFLOWS, FINANCIAL INTERMEDIATION, AND AGGREGATE DEMAND: EMPIRICAL EVIDENCE FROM MEXICO AND OTHER PACIFIC BASIN COUNTRIES

Steven B. Kamin and Paul R. Wood

NOTE: International Finance Discussion Papers are preliminary materials circulated to stimulate discussion and critical comment. References in publications to International Finance Discussion Papers (other than an acknowledgment that the writer has had access to unpublished material) should be cleared with the author or authors. Recent IFDPs are available on the Web at www.bog.frb.fed.us. 


\title{
CAPITAL INFLOWS, FINANCIAL INTERMEDIATION, AND AGGREGATE DEMAND: EMPIRICAL EVIDENCE FROM MEXICO AND OTHER PACIFIC BASIN COUNTRIES
}

\author{
Steven B. Kamin and Paul R. Wood ${ }^{*}$
}

\begin{abstract}
In trying to explain the balance-of-payments and banking crises of 1994-95 that erupted in Mexico, observers have pointed to various effects of the substantial capital inflows that took place in the preceding half decade. It has been argued that these inflows contributed to rapid monetary growth, real appreciation of the peso, and the widening of Mexico's current account deficit. In addition, by making available credit for consumption loans at a time when investment spending in Mexico was not yet ready to grow rapidly, these inflows may have contributed to the fall in Mexico's savings rate.

This paper looks at the effect of capital flows on macroeconomic and financial variables in Mexico during the 1980s and 1990s and compares Mexico's experience with that of a cross-section of Pacific Basin countries. In particular, we attempt to gauge the effect of capital flows on money growth, interest rates, consumption and investment. We do find evidence of an independent effect of capital flows on monetary conditions and domestic demand, controlling for certain other domestic factors. However, these inflows appear not to have altered substantially the basic trajectories of money, consumption, and investment in the recipient countries.
\end{abstract}

Keywords: capital flows, Mexico

\footnotetext{
* The authors are, respectively, Senior Economist and Economist, International Finance Division, Board of Governors of the Federal Reserve System. We are grateful to members of the International Finance Division Workshop for helpful comments and suggestions. David Carter provided excellent research assistance. This paper represents the views of the authors and should not be interpreted as reflecting those of the Board of Governors of the Federal Reserve System or other members of its staff.
} 


\section{Introduction}

In recent years, a substantial literature has emerged to focus on the effects of capital inflows on macroeconomic performance in emerging market countries. Clearly, capital inflows are necessary to finance the excess of investment over savings needed to build productive capacity and accelerate the process of growth in developing economies. However, recent experience has caused observers to take notice of a broad array of less desirable side effects associated with heavy inflows of foreign capital.

First, such inflows may lead to an appreciation--both real and, perhaps, nominal--of the domestic currency, thereby inhibiting export growth and encouraging the widening of current account deficits. Second, to the extent that capital inflows lead to accumulations of international reserves by the central bank, this may lead to undesirable increases in the money supply and in the balance sheets --both assets and liabilities--of domestic banks. The expansion of loanable funds available to domestic banks, in turn, may finance greater increases in consumption and/or investment than are sustainable over the longer run, leading to a further deterioration of external balance, increases in private net indebtedness, and the emergence of non-performing loan problems. Observers acknowledge that the most obvious policy response to such developments--sterilization--may be too costly for governments to pursue on a sustained basis ${ }^{1}$. Third, capital flows are volatile; economies that become too dependent upon capital inflows to finance current account deficits and maturing debts may become significantly destabilized if some factor leads to a reversal of these flows.

However, notwithstanding considerable theoretical analysis and anecdotal evidence linking capital inflows to macroeconomic problems in emerging market economies, there has been little formal statistical analysis of the impact of capital inflows on monetary growth, banking activity, and aggregate demand. Such statistical analysis may be needed to distinguish the particular economic effects of capital inflows from the effects of other developments occurring simultaneously. Many of the emerging market economies experiencing heavy capital inflows during the early 1990s also were in

1 The cost of sterilization is generally taken to be proportional to the interest rate spread between domestic and reserve currency bonds. However, that cost may be exaggerated to the extent that the spread is compensation for expected depreciation of the domestic currency. 
the midst of macroeconomic stabilization, structural reform and financial liberalization. It is possible that some undesirable economic developments that have been attributed to capital inflows may actually be the result of other changes taking place at the same time.

An example from Mexico's recent experience serves to highlight this problem. During the 1990-1993 period, total net capital flows into Mexico rose to an average of $\$ 23$ billion annually from \$2 billion annually during the preceding 1982-1989 period. At the same time, the growth of monetary aggregates, credit, and aggregate demand picked up markedly. It is natural to attribute the rapid monetary growth that took place in Mexico since the late 1980s to the surge in capital inflows. However, this surge in capital inflows took place concurrently with, and may to some degree have been caused by, a marked reduction in Mexican inflation. The Mexican government at that time was, to a first approximation, targeting the interest rate rather than the money supply, and reduced the nominal interest rate in line with the decline in inflation. This, in turn, may have induced an increase in the demand for real money that was accommodated by the monetary authority. In retrospect, therefore, it is not clear whether the growth in real balances that took place in the early 1990s was attributable more to capital inflows or to the decline in inflation. Put another way, it is possible that even in the absence of heavy capital inflows, the authorities would have stepped up domestic credit creation so that monetary growth would still have picked up.

If the rapid monetary growth, banking expansion, and increases in domestic absorption observed in many emerging market economies are being mistakenly attributed to capital inflows, this could lead governments to implement inappropriate policies in order to counter such inflows. The purpose of this paper is to make a rough, initial stab at gauging empirically the extent to which capital inflows have altered macroeconomic performance in emerging market economies.

We start out with an econometric analysis of the impact of capital inflows on interest rates, the domestic money supply, consumption, and investment in Mexico. To analyze the impact of capital inflows on the supply of broad money (M2), we estimate a monetary "reaction function" that relates 
the domestic interest rate targeted by the authorities to its various determinants, including inflation, output, and different measures of capital inflows. We then estimate a model of the demand for M2, based on interest rates and output. These results allow us to assess the impact of capital inflows on interest rates and hence the demand for money, once the evolution of domestic factors is held constant.

We then gauge the effects of capital inflows on Mexican consumption and investment rates, and the extent to which these effects were associated with the domestic financial intermediation of foreign capital inflows. We estimate separate econometric models relating consumption and investment to a standard set of determinants--output growth and interest rates--as well as different measures of capital inflows. These regressions allow us to identify the impact of capital inflows on consumption and investment, controlling for their standard determinants. We also attempt to distinguish the effects on consumption and investment of different categories of capital inflows such as portfolio investment and foreign direct investment.

In the final part of the paper, we seek to identify whether our broadest conclusions about the effects of capital inflows in Mexico apply to the experience of other Pacific Basin countries-Argentina, Brazil, Chile, Colombia, Indonesia, Korea, Malaysia, the Philippines, and Thailand--that experienced substantial capital inflows in the late 1980s and early 1990s. Using a pooled time series/cross-section set of annual data for the ten countries (including Mexico), we estimate econometric equations to gauge the effect of capital inflows on the money supply, consumption, and investment spending in a manner analogous to our analysis of Mexico. We determine whether there are significant differences in the response of economies in different regions to capital inflows, and also consider whether differences in the composition of capital inflows may help explain differences in macroeconomic performance between Latin America and East Asia. 


\subsection{Previous Empirical Work on Capital Inflows}

Formal statistical research on capital flows to developing countries has, until very recently, focused primarily on the determinants of these capital flows. Calvo, Leiderman, and Reinhart (1993) applied vector-autoregression (VAR) analysis to the behavior of recent capital inflows--proxied by changes in international reserves--in several Latin American countries, and determined that external factors such as declines in U.S. interest rates accounted for much, but not all, of the increases in capital inflows during the 1990s. Chuhan, Claessens, and Mamingi (1993) and Fernandez-Arias (1994) came to similar conclusions, but disagreement persists concerning the relative weight of external and domestic factors in the determination of capital flows to emerging market countries.

A related issue has centered on the different time-series properties of different types of capital inflows. According to the conventional wisdom that has developed on this subject, portfolio inflows are much more volatile than other types of capital inflows, particularly direct foreign investment. (See Corbo and Hernandez, 1994.) Claessens, Dooley, and Warner (1995), however, showed that, based on comparisons of the statistical time-series properties of the various categories of capital flows, foreign direct investment and other forms of long-term flows were as volatile and prone to reversal as short-term portfolio flows. These results have tended to qualify views that foreign direct investment should be regarded as more desirable than portfolio flows.

In contrast to the research into the determinants of capital inflows, empirical work on the macroeconomic effects of capital inflows in the recipient economy has been, until recently, based mainly on case studies and generalizations from country experiences. (See, among others, Corbo and Hernandez, 1994, Calvo, Leiderman and Reinhart, 1994, Fernandez-Arias and Montiel, 1995, Khan and Reinhart, 1995, Spiegel, 1995, and Koenig, 1996.) These studies highlight various possible sideeffects of capital inflows that may occur, in addition to their expected effect of boosting investment and the importation of capital goods:

- $\quad$ Capital inflows are likely to appreciate the real exchange rate, either (1) by appreciating the 
nominal exchange rate in a floating exchange rate regime, or (2) by boosting the money supply, aggregate demand, and hence non-tradeables prices in a fixed exchange rate regime. - In a fixed exchange rate regime, as noted above, unsterilized capital inflows may result in some loss of monetary control, resulting in higher monetary growth than otherwise would occur. This (perhaps) undesired monetary expansion may be the vehicle by which capital inflows lead to upward pressure on prices and aggregate demand, real appreciation, and hence a corresponding expansion of the current account deficit. Sterilization of capital inflows is likely to be costly and, if it keeps interest rates high and thereby encourages more capital inflows, ineffective.

- $\quad$ The intermediation of capital inflows through the domestic banking system may be an important feature of the process by which capital inflows lead to demand expansion. Increases in the monetary base resulting from unsterilized intervention lead to an expansion of bank deposits and a corresponding expansion of bank loans. In an environment where the supervision and regulation of banks are imperfectly implemented, the expansion of bank balance sheets associated with capital inflows may enhance the prospects for financial fragility.

- $\quad$ The effect of capital inflows on expanding the money supply, lowering interest rates, and expanding credit availability may well raise consumption (reduce savings) as well as increase investment. This is especially likely to occur if, prior to the resumption of capital inflows, consumption lending had been more tightly rationed than investment lending, so that in response to an easing of constraints, consumption spending rebounded to its unconstrained level.

- It is possible that certain types of capital inflows may generate different macroeconomic effects than others. Foreign direct investment (FDI), for example, would appear, a priori, to be least likely to lead to expansions of the money supply, bank loans and consumption, 
since FDI may be expected to lead immediately to corresponding imports of capital goods, thereby evading intermediation through the domestic financial system. Conversely, portfolio investment would seem more likely to lead to domestic monetary and bank loan expansion, and hence more likely to encourage consumption as well as investment.

While all the effects of capital inflows described above have, to one degree or another, been observed in countries experiencing heavy inflows in recent years, relatively little work has been done so far to evaluate these effects econometrically. However, in the past year, a number of papers have emerged to explore the impact of capital flows on macroeconomic outcomes using formal statistical methods.

Gunther, Moore, and Short (1996) focus on the case of Mexico and estimate a quarterly VAR comprised of the price level, output, foreign investment, international reserves, and the exchange rate. They find that shocks to foreign direct investment had little impact on Mexico's macroeconomic indicators, but that shocks to reserves and to portfolio investment significantly affected output and the exchange rate, thereby adding support to the view that different types of capital flows have different macroeconomic effects.

Gruben and McLeod (1996) analyze a multi-country set of annual data to evaluate the effects of different types of capital flows on macroeconomic performance, and vice-versa. They find considerable evidence of two-way causation between capital flows and output growth, but this evidence weakens in some instances when sub-categories of capital flows or countries are considered; for example, Asian growth is found to be less sensitive to capital inflows than Latin American growth. Capital inflows are found to affect savings rates positively, contradicting the conventional wisdom; interestingly, however, this result is significant only if Mexico is excluded from the sample.

Using instrumental variables estimation, Gruben and McLeod find stronger results for the effects of capital flows on growth, with foreign direct investment being somewhat more significant 
than equity portfolio flows in this regard. On the other hand, with instrumental variables estimation, the positive effect of capital inflows on savings becomes insignificant.

Antzoulatos (1996) takes an approach similar to Gruben and McLeod (1996), focusing on the impact of capital flows on the components of domestic demand in a multi-country panel of annual data. He finds that in Latin American countries, domestic demand, private consumption, government consumption, and investment all responded positively and significantly to the (scaled) levels of international reserves and of borrowings in international bond markets. Conversely, capital inflows were found not to significantly affect measures of Asian domestic demand in most specifications of the estimating equation, consistent with Gruben and McLeod, while only investment consistently showed a significant response to the level of international reserves.

On balance, the results of the empirical work surveyed above provide tentative evidence that capital inflows did have significant impacts on the macroeconomic performance of emerging market economies in the 1990s. Further work in this area must address the following concerns, among others. First, the effects of structural reforms, stabilization programs, and other domestic developments need to be controlled for, so that the independent effect of the capital flows themselves can be identified more clearly. Second, further empirical work should address the channels through which capital flows influence the economy--exchange rates, bank loans, asset prices, etc.--not merely the reduced form linking capital flows to their final macroeconomic outcomes. Finally, it would be of interest to understand the magnitude of the impact of capital flows on the macroeconomic performance of emerging market countries in recent years, not merely whether that impact was statistically significant or not.

\section{The Evolution of Capital Flows and Economic Performance in Mexico: 1988-1994}

\subsection{Capital Flows}

During the 1990s, Mexico experienced a nearly unprecedented inflow of foreign capital, 
coming after a period--coinciding with the debt crisis--when net inflows had all but dried up. As indicated in Chart 2.1, after averaging about $\$ 2$ billion annually during 1982-1988, net inflows rose to $\$ 8$ billion in 1990 and $\$ 33$ billion by 1993 . The inflows, however, were distinctive in terms of the greatly increased importance of portfolio investment and the greatly decreased importance of bank borrowing.

Various factors explain the resurgence of capital inflows into Mexico during the 1990s. On the domestic side, the attractiveness of Mexican investments was raised by a series of reform and stabilization measures undertaken in the latter part of the 1980s and the early 1990s, including the lowering of trade barriers, the liberalization of the financial system and privatization of banks that had been nationalized in 1982, and the near elimination of the fiscal deficit. These reforms were coupled with a stabilization program, initiated in 1988, aimed at reducing the depreciation of the peso against the dollar and using agreements with labor and business to moderate wage and price increases. As evident in chart 2.2, the peso stabilized dramatically, the rate of inflation declined from nearly 160 percent in 1987 to 7 percent by 1994, while GDP growth, which on balance had been nearly flat for the $1982-87$ period, rose to relatively high levels by the early 1990 s.

However, the surge in capital inflows did not begin in earnest until 1990, well after inflation had come down and output had begun to recover. A second important factor in stimulating capital inflows may well have been the Brady Plan for debt reduction, which Mexico signed with its commercial bank creditors in February 1990. An indication of the importance of the Brady Plan was the downtick in peso-denominated interest rates, shown at the top of chart 2.3 , in the months after the deal was signed.

Finally, the inflow of capital into Mexico undoubtedly was spurred by the decline in U.S. interest rates, as Calvo, Leiderman and Reinhart (1993) have shown. The search for higher rates of return outside the United States, coupled with the discrediting of direct bank lending in the aftermath of the debt crisis, probably explain much of the shift from bank lending to portfolio investment in the 
composition of capital inflows into Mexico and other emerging market countries.

\subsection{Monetary and Banking Conditions}

As shown in the bottom panel of chart 2.3 , measures of the monetary aggregates--M2 and the monetary base--expanded strongly during the 1990s. However, the extent to which monetary expansion can be attributed directly to capital inflows is not clear a priori. First, the Bank of Mexico actively sterilized reserve inflows so that, over the period, most increases in net foreign assets were offset by reductions of net domestic credit. Second, the real monetary base began to grow strongly in 1988 and slowed somewhat after 1990; conversely, real M2 did not pick up until 1989 and exhibited very strong growth after 1990. This suggests that much M2 growth resulted from increases in the money multiplier linking M2 to the monetary base, rather than balance-of-payments induced expansions of the monetary base itself. Finally, and as related point, the top panel of chart 2.1 indicates that the surge in capital inflows led to the strongest rate of reserve accumulation only in the 1990-91 period, after which, capital inflows primarily served to finance larger current account deficits. Nevertheless, real M2 growth remained strong throughout the period, suggesting, again, that if capital inflows tended to boost monetary growth, they must have done so through means other than reserve accumulation and monetary base expansion per se.

The top panel of chart 2.3 indicates that along with an expansion of the monetary aggregates, the period of capital inflows was associated with sharp reductions in real interest rates as well as nominal interest rates. It is obvious that much of the reduction in nominal interest rates cannot be attributed to capital inflows, since the most marked decline occurred in 1988, prior to the recovery of capital inflows and coincident with the inflation stabilization program. On the other hand, ex post real interest rates were quite high in 1988 and 1989, perhaps serving to jumpstart capital inflows, and declined in subsequent years as capital inflows reached their peak.

Finally, the reduction in inflation and interest rates, rise in the monetary aggregates, and 
recovery of access to international credit markets was accompanied by a recovery of bank lending to the non-financial private sector, shown in the bottom panel of chart 2.3. As may be seen on that chart, however, the turnaround in bank lending actually preceded the recovery of M2. This may reflect the fact that the rise in bank lending reflected not only increases in the liabilities of the banking system--which increased loanable resources--but also the decline in the use of these resources to finance the public sector deficit, which declined from 15 percent of GDP in 1987 to approximate balance by the early 1990s.

\subsection{Savings and Investment}

One of the most important criticisms of capital inflows is that, at least in some Latin American countries, they have encouraged--or at least, financed--an increase in consumption rather than in investment. Table 2.1 compares the evolution of savings, investment, and the current account as a share of GDP. Comparing 1994 with 1985, of the roughly 8 percent of GDP deterioration in the current account balance, a reduction in savings accounts for 6 percent of GDP and an increase in total investment spending only 2 percent of GDP. On the face of it, therefore, capital inflows financed greater consumption more than greater investment. However, the relatively small increase in the total investment rate in part reflects a 2 percent of GDP drop in public investment resulting from government budget-cutting. Private fixed investment rose about 4 percent of GDP, somewhat closer in magnitude to the rise in consumption.

Finally, it is worth noting that the sharpest reduction in the savings rate took place between 1987 and 1989, before capital inflows had begun to recover in earnest. Conversely, private investment did not begin to recover until after 1990, coincident with the largest increases in capital inflows. Hence, the prima facie evidence is at best mixed that capital flows encouraged consumption more than investment in Mexico. 


\section{The Impact of Capital Flows on Domestic Money Demand in Mexico}

3.1 Theory

Capital flows conventionally are believed to affect directly the supply, rather than the demand, for money. Therefore, in principle, to assess the effect of capital flows on monetary growth in Mexico, we might focus on the transmission channel linking capital flows to international reserve changes, net foreign assets, the monetary base, and hence the broader monetary aggregates. However, as we show below, these linkages are not likely to remain constant over time.

Equation (1) establishes M2 as being linked through the money multiplier ( $\mathrm{mm}$ ) to the monetary base $(\mathrm{MB})$ :

$$
M 2=m M M B
$$

Therefore, changes in M2 reflect changes in either the monetary base or the money multiplier:

$$
\Delta M 2=M B \Delta m m+m m \Delta M B
$$

The change in the monetary base, in turn, depends upon changes in net foreign assets (NFA) and net domestic assets (NDA) of the central bank:

$$
\Delta M B=\Delta N F A+\triangle N D A
$$

The central bank determines the evolution of NDA directly. NFA is determined as the local currency equivalent of international reserve changes (we assume, for convenience, that the exchange rate $\mathrm{E}$, pesos per dollar, is fixed):

$$
\Delta N F A=E \Delta R
$$

Reserve changes, in turn, are the sum of the current account (CA) and the capital account (KA):

$$
\Delta R=C A+K A
$$

Putting together equations (2) through (5): 


$$
\Delta M 2=\Delta m m M B+m m(\Delta N D A+E(C A)+E(K A))
$$

In principle, therefore, the impact of a change in capital flows on monetary growth can be calculated:

$$
d(\Delta M 2) / d(\Delta K A)=m m E
$$

Equation (7), however, presupposes that changes in capital flows affect neither the current account (CA) nor net domestic assets (NDA). (It also is assumed that the exchange rate $\mathrm{E}$ remains fixed.) In practice, both CA and NDA are likely to be affected by a change in capital flows. Hence, a more comprehensive description of the impact of capital flows on monetary growth can (after some manipulation) be derived:

$$
\begin{gathered}
d(\Delta M 2) / d(\Delta K A)= \\
m m E(1+d(\Delta N D A) / d(\Delta N F A))(d C A / d K A+1)+M B(d(\Delta m m) / d K A)
\end{gathered}
$$

Equation (8) suggests that the impact of capital inflows on the supply of M2 will depend upon the initial values of the money multiplier and the exchange rate, the extent to which changes in capital flows elicit changes in the current account balance, the extent to which the authorities sterilize changes in the monetary base resulting from reserve changes $(\mathrm{d}(\Delta \mathrm{NDA}) / \mathrm{d}(\Delta \mathrm{NFA}))$, and any impacts of capital inflows on the money multiplier.

In practice, various of the derivatives embedded in equation (8) are likely to vary over time. The extent to which the monetary authorities sterilize capital inflows will depend on the present state of the economy. The extent to which changes in the capital account lead to changes in the current account may depend upon whether or not the economy is constrained in its access to international credit markets. Finally, the removal of reserve requirements in Mexico starting in 1988 means that the money multiplier subsequently has been determined very much by market conditions; it therefore is likely that capital inflows had a different (probably, much smaller) impact on the money multiplier 
before the removal of reserve requirements compared with afterward. The bottom panel of chart 2.3 indicates that the money multiplier rose substantially in the 1990s.

In sum, explaining the surge in M2 growth that took place in Mexico in the early 1990s by decomposing the sources of the supply of M2 is likely to be fraught with difficulty. We therefore take an alternative approach in this paper, and attempt to gauge the impact of capital inflows on the demand for M2. In this approach, we start with a conventional money demand function--a simple, static example of this function, in which M2 demand depends upon a domestic interest rate $\mathrm{i}$ and real income $y$, is shown below.

$$
\log (M 2 / P)=\alpha-\beta i+\delta y+e_{M}
$$

Assuming that the demand curve for M2 remains stable, capital inflows can only affect M2 in the long run by affecting its demand--in the first instance, this means by affecting interest rates. As in Kamin and Rogers (1996), we posit an interest rate reaction function for the monetary authority, in which the authority sets the domestic interest rate in response to the prevailing level of inflation, output growth, and capital inflows. Increases in inflation lead the authorities to raise interest rates to keep the real interest rate from declining. Increases in output growth also should elicit a countercyclical rise in interest rates. Finally, increases in capital inflows induce the authorities to lower interest rates because (1) they bolster the monetary authorities' reserve position and hence reduce the need for additional inflows, and/or (2) capital inflows are costly to sterilize, and lowering interest rates both implies less sterilization and smaller future inflows. An illustrative static version of an interest rate reaction function is shown below:

$$
i=v+\lambda \hat{P}+\phi \hat{y}-\theta K A+e_{i}
$$

The interest-rate reaction function approach is supported by the fact that during most of the period prior to the December 1994 devaluation, the authorities appeared to be targeting the interest rate rather than a monetary aggregate. Kamin and Rogers estimated a dynamic version of an interest rate 
reaction function which they found to be quite stable during the early 1990s in Mexico.

Based on equations (9) and (10), the impact of capital flows on money demand can be calculated as a function of the impact of KA on $i$, and then the impact of $i$ on M2:

$$
d M 2 / d K A=(d M 2 / d i)(d i / d K A)=(-\beta)(-\theta)>0
$$

\subsection{Estimation Strategy}

In this paper, we take two related approaches toward calculating the impact of capital flows on money growth, as shown in equation (11). First, we estimate dynamic versions of equations (9) and (10) separately, and simulate a counterfactual path of interest rates and money balances that would have occurred, had capital inflows not surged as they did in the early 1990s.

Second, we add capital inflows as an explanatory variable in the money demand function (equation 9), and estimate it using two stage least squares. Merely adding capital inflows (KA) to equation 9 and estimating OLS is problematic, since the interest rate in equation (9) already incorporates the effects of capital inflows. However, consider the result when we substitute equation (10) for the interest rate in equation (9) and slightly re-arrange terms:

$$
\begin{aligned}
\log (M 2 / P) & =\alpha-\beta\left(v+\lambda \hat{P}+\phi \hat{y}-\theta K A+e_{i}\right)+\delta y+e_{M} \\
= & \alpha-\beta\left(v+\lambda \hat{P}+\phi \hat{y}+e_{i}\right)+\beta \theta K A+\delta y+e_{M}
\end{aligned}
$$

The terms within parentheses in the second line represent that part of interest rates that is not determined by capital flows, while the $\theta \mathrm{KA}$ term represents that part of interest rates that is a function of capital flows. We estimate (a dynamic version of) equation (12) through a two-stage procedure in which we first estimate a partial version of the interest rate reaction function equation:

$$
i=\boldsymbol{v}+\lambda \hat{P}+\phi \hat{y}+\sigma Z+e_{i}
$$

$\mathrm{Z}$ represents other potential instruments that are correlated with the interest rate (i) but not with KA. We then take the fitted values for i, denoted i', and use them as explanatory variables in the second 
stage regression:

$$
\log (M 2 / P)=\alpha-\beta i^{\prime}+\beta \theta K A+\delta y+e_{M}-\beta e_{i}
$$

Estimating equation (14) has an advantage over estimating equations (9) and (10), in that it is more general and imposes fewer restrictions on the data. First, it does not pin down the specific model linking capital flows to the interest rate. Second, it does not restrict KA to affect M2 demand exclusively by affecting interest rates. For example, KA may affect M2 directly by raising foreign currency (mainly dollar) deposits in Mexico, without requiring a reduction in peso-denominated interest rates to raise the demand for those deposits.

Finally, as in our first approach, we use the estimated version of equation (14) to determine how the money supply would have evolved, had capital flows not surged into Mexico in the early 1990s. These results can then be compared to those calculated using our first, explicitly two-equation strategy. 


\subsection{Equation Specification and Estimation Results from the Two-Equation Approach}

In implementing our first approach to gauging the effect of capital inflows on money demand in Mexico, we use quarterly data for 1982 to 1994 to separately estimate error-correction versions of the static money demand and interest-rate reaction functions shown in equations (9) and (10). We use two different measures of capital inflows: the capital account, which measures the net flow of capital into Mexico, and the change in international reserves, which measures the extent to which capital flows would increase the monetary base absent any sterilization. We scale the capital account variables, expressed in terms of nominal pesos, by dividing them by lagged nominal balances of M2. The interest rate used here is the rate on 28-day cetes (peso-denominated Mexican treasury bills). The inflation rate used is the log change in the consumer price index.

Focusing first on the specification of the interest rate reaction function, we start out with the most general specification of an error-correction function, where we regress the change in the interest rate on changes in the explanatory variables and lagged levels of the interest rate and the explanatory variables.

$$
\begin{gathered}
\Delta i=\alpha+\lambda \hat{P}_{-1}+\phi \hat{y}_{-1}+\theta K A_{-1} \\
+\sum_{n=1}^{4} \rho_{n} \Delta i_{-n}+\sum_{n=0}^{4} \lambda_{n} \Delta \hat{P}_{-n}+\sum_{n=0}^{4} \phi_{n} \Delta \hat{y}_{-n}+\sum_{n=0}^{4} \theta_{n} \Delta K A_{-n}
\end{gathered}
$$

This is then reduced by progressively removing explanatory variables with non-significant coefficients, following Hendry's general-to-specific approach. We end up with a parsimonious equation similar to that in Kamin and Rogers (1996). As in Kamin and Rogers (1996), we were unable to estimate a coefficient on an output variable that was statistically significant and of the expected positive sign, and hence we dropped it from the equation.

The first column of table 3.1 shows the results from estimating the basic interest-rate equation without the capital flow variables. The lagged interest rate enters with the expected negative sign while lagged inflation and the change in inflation both enter with the expected positive sign. The second column shows that, when the lagged value of the capital account and the change in the capital 
account are included, they are estimated to have a significant negative effect on the change in the interest rate. The third column shows that the lagged value of the change in reserves and the change in the change in reserves also have significant negative effects on the change in the interest rate. These results are consistent with the theoretical presumption that capital inflows can reduce the interest-rate target of the central bank, either by lessening concerns over depleting international reserves or by reducing pressure for the exchange rate to depreciate.

The fourth column of table 3.1 shows the results of including both the capital account and the change in reserves in the interest-rate equation. The change in reserves continues to show a significant negative effect on the interest rate, but the effect of the capital account largely disappears. This suggests that reserves may have a structural relationship with the interest rate while the capital account may affect the interest rate only indirectly, through its effect on reserves. That is consistent with the central bank caring about the reserve level but not caring about other effects of capital inflows.

The second stage of this two-stage approach to gauging the impact of capital inflows on M2 money growth is to examine the effect of interest rates on money demand. The first column of table 3.2. shows the results from estimating a parsimonious model of money demand used in Kamin and Rogers (1996), where the log-change in real, seasonally-adjusted M2 money demand depends negatively on the interest rate, positively on the four-quarter change in the interest rate, and negatively on the inverse of lagged velocity (real M2/GDP).

\section{Simulation Using the Two-Equation Approach}

We now attempt to gauge the impact of net capital flows on Mexican money demand during the 1988-94 period. Using the estimation results for the effect of capital flows on the interest rate from table 3.1 and for the effect of the interest rate on the M2 money supply from the first column of table 3.2., we simulate the path that interest rates and M2 would have taken if net capital 
inflows during 1988-94 had been zero. To do this, we first add-factor the estimated interest rate and M2 equations by adding the estimated residuals over the 1988-94 period back into them so that a dynamic simulation over that period yields the actual observations of the left-hand side variables. Next, we dynamically simulate the interest rate equation with the net capital flow variable set to zero over 1988-94. Finally, we substitute the simulation results for the interest rate into the M2 equation and then dynamically simulate it over the 1988-94 period. We do this exercise twice, once using the capital account and as the net capital flow variable and once using the change in reserves as a proxy for net capital flows.

Chart 3.1 compares the actual path of Mexican interest rates with those simulated by the model, once the net capital flows variable is set to zero for the 1988-94 period. The top panel indicates that when the entire capital account is used as the net capital flows variable, setting that variable to zero results in a substantial increase in interest rates. This suggests that the capital inflows that took place in 1988-94 appreciably reduced Mexican interest rates. However, in the bottom panel, the change in international reserves is used as the capital flows variable, and setting this term to zero results in a much smaller rise in interest rates. In fact, since reserves actually declined in 1988 and early 1989, setting reserve changes to zero actually leads simulated interest rates to decline relative to actual in those years.

Based on the two simulated paths of interest rates, under the counterfactual hypothesis that net capital inflows were zero during 1988-94, chart 3.2 compares the resultant simulated paths of real M2 in this period to their actual values. Regardless of whether the entire capital account or reserve changes are used as the proxy for net capital inflows, simulated real M2 (under the counterfactual hypothesis that net capital inflows are zero) rises strongly and persistently from its 1989 low point during the 1990s. This suggests that, even in the absence of strong capital inflows, other economic developments (perhaps, in particular, the reduction in inflation) would have induced declines in interest rates, substantial increases in money demand, and correspondingly substantial increases in money 
supply.

The counterfactual experiment using the entire capital account as a proxy for capital inflows (the top panel) suggests that capital inflows had a substantial effect in further boosting real M2, while the experiment using reserve changes (the bottom panel) indicates that capital inflows had a relatively minor effect on monetary growth. (These results mirror those for interest rates in chart 3.1) This inconsistency in the results largely reflects the divergence between decelerating reserve accumulation and continued strong capital inflows after 1991. In attempting to reconcile the inconsistency, one possibility is that the results shown in the top panel are spurious. That is, as indicated in the estimation results in Table 2.1 (fourth column), capital inflows may affect monetary conditions only insofar as they affect reserves. In that case, the strong growth of real M2 in 1992-93, even as the capital account surplus surged relative to the pace of reserve accumulation, may have been merely a coincidence, not a causal outcome.

An alternative possibility is that the channels through which the capital account influenced monetary conditions changed during the 1990s. On balance over the entire 1982-1994 estimation sample, it is possible that reserve changes (through their effect on the monetary base) were the proximate causes of monetary growth, and that the capital account affected monetary conditions mainly through its impact on reserve changes. However, during the 1990s, other determinants of monetary conditions may have become important, and these determinants may have been more directly influenced by the capital account. Chart 2.3 shows that the ratio of M2 to the monetary base started rising in mid-1990, about the same time as capital inflows began to come into Mexico. It is possible that the regaining of access to international financial markets, combined with financial liberalization and reductions in public sector borrowing, led to increases in the money multiplier that substantially raised monetary growth.

3.4 Estimation and Simulation Results from the One-Equation Approach to Estimating M2 Demand 
Our second approach to estimating the demand for M2 is to directly include the capital flow variables in the M2 demand equation shown in equation (9). The second column of table 3.2. shows the estimation results when the capital account is included in the parsimonious model of M2 money demand. Even with the interest rate and the four-quarter interest-rate change in the equation, the capital account has some positive effect on the demand for M2 balances. As shown in the second column of table 3.3., the same is true for the change in reserves.

However, these estimates of the effect of capital inflows on M2 may be biased if, as discussed in section 3.1, capital flows affect monetary conditions primarily by affecting the interest rate, since the interest rate already is included as an explanatory variable in the M2 equation. Therefore, as discussed in section 3.1, in order to measure the total effect of capital flows on M2 demand, we use instrumental variables estimation to constrain the interest rate from moving in response to contemporaneous capital flow indicators, while allowing it to move in response to contemporaneous domestic variables such as inflation as well as lagged external variables. This allows the coefficient on the capital flow variable to capture all of its effects on M2 demand, including those working through the interest rate. As indicated in the third column of tables 3.2 and 3.3, the use of instrumental variables has the effect of raising somewhat the size and significance of the coefficients on both the capital account and reserve changes. Finally, the fourth columns of tables 3.2 and 3.3 indicate the effects of instrumenting for the capital flow variable as well; this will be discussed further in the next sub-section.

We now repeat the counterfactual simulation experiment shown in charts 3.1 and 3.2 , but using our one-equation approach to gauging the effect of capital flows on M2 demand. Chart 3.3 shows the simulation of what would have happened to real M2 if net capital flows had been zero during the 1988-94 period, using the results from the estimation of the M2 demand equation (we use the estimation results shown in the third column of table 3.2 for the capital account and the fourth column of table 3.3 for reserve changes). As in the two-equation approach, we find that even after 
setting the capital inflow variables (both the capital account and reserve changes) to zero, the resultant simulated growth of real M2 still is quite substantial; in fact, the measured impact of capital flows on M2 is smaller under the one-equation approach than it is under the two-equation approach. Hence, these results reinforce our view that much of the rebound in the monetary aggregates after 1988 was not attributable to capital inflows. Additionally, the one-equation results indicate, as in the case of the two-equation results, that the capital account appears to have affected monetary growth more than reserve changes in the 1990 s.

\subsection{Simultaneity Issues}

We address three distinct simultaneity issues. First, in the conventional money demand function, the interest rate may be endogenous with respect to shocks to the supply of money, leading to simultaneity bias in the estimation of equation (9). In practice, however, simultaneity bias does not appear to be a problem here, as instrumental variables estimation of equation (9), shown in the third column of tables 3.2. and 3.3., results in very little change to estimated coefficients on the interest rate and the four-quarter change in the interest rate. Using the fitted values does increase moderately the coefficient values of the capital flow variables (also shown in the third column of tables 3.2. and 3.3.), suggesting that at least some of the effect of capital flows on M2 demand is through the interest rate.

A second source of simultaneity bias stems from the endogeneity of capital flows with respect to the domestic interest rate. As indicated in equation (16) below, capital inflows probably respond to various factors, including deviations from uncovered interest parity, a country risk premium (RP), and other country-specific factors (X) that may influence the profitability of foreign investments. To the extent that movements in domestic interest rates (i) account for much of the variation of capital flows (KA), this raises two concerns. First, it may lead to significant bias in the estimation of equations (10) and (14)--in principle, it could even lead to estimation of a positive coefficient on KA in the interest rate equation (10) and a negative coefficient in the money demand equation (14). 
Second, the endogeneity of capital flows may undermine the relevance of seeking to determine the effects of capital flows, rather than their underlying determinants, on macroeconomic performance.

$$
K A=\kappa+\xi\left(i-i *-\hat{E}^{e}\right)-\vartheta R P+\varrho X+e_{K A}
$$

The estimation results, however, suggest that the endogeneity of capital flows with respect to domestic interest rates probably is more apparent in theory than in practice. First, as was seen in table 3.1, when dynamic specifications of equations (10) and (14) are estimated using OLS, coefficients on the capital flow variables are estimated with their expected signs. Second, the instrumental variables estimates of equation (14) (instrumenting for the capital flow variables as well as for interest rates) shown in the fourth column of tables 3.2. and 3.3. do not result in large changes in estimated coefficients or their significance. Hence, to a first approximation, it appears that the variation in capital flows is sufficiently explained by non-domestic-interest rate factors so as to make a focus on capital flows, rather than on their underlying determinants, intellectually defensible.

Finally, we should note that the results presented so far only address the direct effects of capital inflows on monetary conditions, and treat domestic conditions such as inflation and output (which was then dropped from the equation) as exogenous. However, inflation and output may have been, to a certain extent, endogenous with respect to capital inflows. To the extent that the reductions in inflation that boosted M2 demand were induced by the fixing of the exchange rate, which in turn was sustained by capital inflows, our estimates of the monetary effects of capital inflows ignore their indirect effect operating through the exchange rate regime. This serves to qualify our interpretation of charts 3.2 and 3.3, to a certain extent, but does not alter our basic conclusion: capital inflows, operating through the standard interest-rate and liquidity channels that are highlighted in the literature, did not significantly alter the evolution of real Mexican M2 during 1988-94.

\section{The Impact of Capital Flows on Consumption and Investment in Mexico}

In this section, we attempt to gauge the impact of capital inflows on Mexican consumption 
and investment in the 1988-94 period. As in the case of Mexican money demand, we attempt to hold constant other factors that might be correlated with capital inflows in order to distinguish the independent impact of the capital flows themselves. Ideally, we would introduce proxies for various stabilization measures and structural reforms that were likely to affect consumption and investment decisions. These factors are difficult to quantify, however, and as a preliminary effort, we include only the more standard, quantifiable determinants of domestic demand: output, output growth, and the real interest rate.

\section{$\underline{4.1 \text { Consumption }}$}

Theoretically, consumption demand will be negatively affected by the cost of funds (proxied by the real interest rate) and will be positively affected by income (real GDP). In addition, to the extent that consumption is constrained by the availability of credit (as distinct from the cost of credit), consumption may also depend positively on the size of bank balance sheets (proxied by M2 balances) and, indirectly, on capital inflows. Copelman and Werner (1996), in particular, find that the quantity of credit available in the Mexican economy does have real effects.

$$
C=\boldsymbol{\beta}_{0}+\boldsymbol{\beta}_{1} G D P+\boldsymbol{\beta}_{2} \text { III }+\boldsymbol{\beta}_{3} M 2+\boldsymbol{\beta}_{4} K A
$$

We estimate an error-correction version of equation (17). The first column of table 4.1 shows the estimation results when capital inflow variables are excluded. The lagged level and change of real GDP both show the expected significant positive effect on consumption. The long-run elasticity of consumption with respect to GDP (the coefficient on lagged real GDP divided by the coefficient on lagged real consumption) is close to unity. The real interest rate does not show the expected negative relationship with consumption, but that is not an uncommon result in this literature. As shown in the second column, the capital account has a nearly significant positive impact on consumption, even with the real interest rate being held constant. 
As noted in Section 1.1, different types of capital flows might have different effects on consumption. In the third and fourth columns of Table 4.1, we include separately in the consumption equation measures of two different types of capital inflow: net foreign direct investment and net foreign portfolio investment (scaled by lagged nominal M2). Neither foreign direct investment (column 3) nor portfolio investment (column 4) has significant impact on consumption, although their coefficients are quite different from each other. To gauge the significance of those differences, we rerun the consumption regression including both the capital account and a sub-capital account variable (FDI or portfolio flows). Those results are shown in the last two columns of table 4.1. The coefficient on a sub-capital account variable measures the marginal effect of a movement in that variable, holding the capital account constant. Both FDI and portfolio flows have an insignificant additional effect when added along with the total capital account, so we cannot reject that their effects on consumption are the same.

\section{The Role of Financial Intermediation of Capital Inflows}

If real M2 is taken as a proxy for bank deposits (and thus bank credit) it would be expected to have a positive effect on consumption, and the inclusion of real M2 in the regression might be expected to reduce the coefficient on the capital account and portfolio investment (because they may work indirectly through their effect on M2). Table 4.2. shows the same regressions as the first four columns of table 4.1, but with the addition of lagged real M2 and the change in real M2. Surprisingly, real M2 has either an insignificant effect or a significant negative effect on consumption. Moreover, its inclusion slightly raises the significance of the capital account variable.

It is possible that M2 is not a good proxy for bank credit. As shown in chart 2.5, real bank loans picked up in 1988, at least a year before the path of real M2 turned upward. Indeed, the path of real bank loans does appear to correspond more closely with that of consumption. When we included real bank loans, instead of real M2, in the consumption equation (not shown), we found a positive but 
insignificant effect of real bank loans on consumption.

Hence, while capital inflows appear to have been associated with increased Mexican consumption, even holding income and interest rates constant, our results do not support the existence of what we had expected to be the primary mechanism through which capital inflows encouraged consumption: increases in the money supply and hence bank lending.

\section{A Counterfactual Simulation Experiment}

To gauge the impact of net capital flows on Mexican consumption during the 1988-94 period, we use the estimation results for the effect of the capital account on consumption from table 4.1 (column 2) to simulate the path that consumption would have taken if the capital account during 1988-94 had been zero. This dynamic simulation uses the same basic approach as the M2 and interest rate simulations described in section 3.3. Chart 4.1 compares the actual path of Mexican consumption with that simulated by the model, once the capital account is set to zero for the 1988-94 period. The chart indicates that Mexican consumption would have been lower in the absence of capital inflows, but that the general pattern of substantial growth in consumption during 1988-94 would not have been altered. That implies that other factors such as the recovery of output, inflation stabilization and financial liberalization may have been more important than capital flows in spurring the surge in consumption.

\section{More Simultaneity Issues}

The equations presented in Tables 4.1 and 4.2, and used to perform the counterfactual simulation in chart 4.1, are subject to various forms of simultaneity bias, but these potential biases do not alter our final conclusion: that capital inflows did not greatly change the path of Mexican consumption during 1988-94. First, capital inflows may well be caused by consumption, rather than vice-versa, to the extent that additional consumption demand leads to additional international 
borrowing. If this were the case, however, then the coefficient on capital flows would be biased upwards, meaning that our estimate of the effect of capital flows on Mexican consumption shown in chart 4.1 was too high. This possibility only reinforces our conclusion that even in the absence of strong capital inflows, Mexican consumption would likely have risen sharply after 1987.

As a second and related issue, the coefficient on the capital flows variable may be informative, even if the causality does run from consumption to capital flows. Presumably, in the event that access to international credit markets is cut off, consumption must be curtailed accordingly. Hence, the counterfactual experiment presented in chart 4.1 may be interpreted as an estimate of the extent to which additional capital inflows permitted additional consumption.

Finally, it is possible that the output measures included in the consumption function are endogenous with respect to capital inflows, so that the counterfactual simulation presented in chart 4.1 captures only the direct effect of capital inflows on consumption, not their indirect effect operating through income. However, private consumption and investment account for most of GDP. Therefore, it is unlikely that capital flows could affect GDP significantly except by affecting consumption and/or investment.

\section{$\underline{4.2}$ Investment}

Table 4.3 shows the results of estimating an equation for private investment in Mexico. In the basic equation without capital inflow variables, we get the expected positive effects of real GDP and the change in real GDP on the change in investment. We also get the expected negative effect of lagged investment. The change in the real interest rate shows a near zero effect on the change in investment. None of the capital flow variables show any clear effect on investment, perhaps suggesting that capital inflows have not been an important determinant of investment in Mexico. These results, together with those presented in tables 4.1 and 4.2 , are consistent with a widespread view that capital inflows financed consumption rather than investment in Mexico. However, these 
results are too preliminary to fully confirm this view.

\section{Tests of the Impact of Capital Flows Using a Multi-Country Data Set}

Our results suggest that capital flows did not substantially alter the basic evolution of Mexican macroeconomic performance in 1988-94. We now consider whether the Mexican experience with capital inflows has been shared by other developing countries that recently experienced significant capital inflows, based on estimated econometric equations for a pooled time series/cross-section set of annual data from 1983 to 1994 for ten developing countries. Our data set includes Mexico, as well as Argentina, Brazil, Chile, Colombia, Indonesia, Korea, Malaysia, the Philippines, and Thailand. We exclude Argentina and Brazil from our interest rate and M2 regressions owing to difficulties introduced by their hyperinflations, but those two countries are included for the consumption and investment regressions.

Looking first at charts 5.1 and 5.2, we can see that overall capital flows, as measured by the capital account as a share of GDP, rose sharply for many of the of the Pacific Basin countries as they did for Mexico during the 1989-93 period. Mexico does appear to stand out, however, in terms of the rise in portfolio investment as a share of GDP. In addition, Mexico's experience with rising broad money balances as a share of GDP was shared by many of the Asian countries in our sample as was, to some extent, the decline in interest rates after 1990.

\subsection{The Impact of Capital Flows on Money Demand}

First, we estimate an interest-rate reaction function such as in equation (9) for the multicountry sample, based on the equation for Mexico described above. We include country dummies that allow a different constant for each country. The results are shown in table 5.1. For the basic equation, without capital flow variables, the lagged interest rate (a short-term money market rate) has the expected negative effect on the change in the interest rate, while the change in inflation and the 
lagged level of inflation enter with the expected positive effects. In addition, the coefficients on the lagged interest rate and lagged inflation are of similar absolute magnitudes, suggesting that the real interest rate in this sample is stationary. As shown in columns 2 through 4 , in contrast to our results for Mexico, the multi-country regressions do not show any significant effect of the capital account or the change in reserves on interest rates. This suggests either that many countries in the sample did not pursue an interest rate target, did not allow capital inflows to affect monetary conditions, or both.

Second, we estimate a demand equation for real M2 such as that in equation (9); it utilizes the conventional lagged-dependent-variable specification rather than the error-correction formulation used previously in this paper . As shown in table 5.2, the log of real GDP has the expected significant positive effect on real M2 while the nominal interest rate has the expected significant negative effect. Whether or not we use a fitted interest rate (using as instruments the inflation rate, the lagged interest rate, and the log of lagged real GDP) to address the endogeneity of the interest rate, we find that the change in reserves has a strongly significant positive effect on real balances while the capital account does not have a significant effect. Thus, as with the estimation results for Mexico alone, we find that the change in reserves has a greater direct impact on the demand for M2 balances than does the capital account.

\subsection{The Impact of Capital Flows on Consumption and Investment}

As we did for the case of Mexico, we estimate an equation for our multi-country sample where real consumption depends on real GDP and the real interest rate. As indicated in table 5.3, we find real GDP, the change in real GDP, and lagged consumption to have a significant and positive effect on consumption (the long-run income elasticity of consumption is close to unity). However, in contrast to our results for Mexico, where the coefficient on the real interest rate was merely insignificant, here the real interest rate had an unexpected significant positive effect, and was dropped from the equation. In the remaining columns of table 5.3, we add alternatively the capital account, 
foreign direct investment (FDI), and portfolio capital flows, each as a share of nominal GDP. We find the capital account to have a significant positive effect on consumption, but coefficients on its subcomponents -- FDI and portfolio flows -- are insignificant. Moreover, both FDI and portfolio flows have small and highly insignificant coefficients when added along with the capital account (the last two columns of Table 5.3), so we cannot reject that their effects on consumption are the same.

Table 5.4 indicates that, as in the Mexican case, we do not find any evidence that real M2 balances positively affect consumption. In fact, as for Mexico, we find that real M2 balances have a puzzling, highly significant negative effect on consumption.

Estimating an investment equation similar to that for Mexico (table 5.5), we find that both the capital account and foreign direct investment have significant positive effects when entered separately and that portfolio investment has a positive but less than significant effect. That contrasts with what we found for Mexico, where none of the capital flow variables had any clear effect on investment. As shown in the last two columns of table 5.5, the coefficients on the capital account subcomponents do not appear to be significantly different from the coefficient on the overall capital account, but, particularly in the case of FDI, this may reflect the low precision of our econometric estimates.

In order to explore whether Latin American countries in our sample have responded differently to capital flows than have the Asian countries, we re-run the consumption and investment equations with regional interaction dummy variables. A summary of the results is shown in table 5.6. While estimated coefficients of response differ somewhat between Latin America and Asia, these differences are not statistically significant, as reflected in the low t-statistics on the interaction dummies.

\section{$\underline{\text { Counterfactual Simulation Experiments }}$}

To gauge the impact of the capital account on consumption and investment in the ten 
countries in our sample, we use the results from the multi-country panel regressions (second column of tables 5.3 and 5.5) to simulate the path that consumption and investment would have taken in each of the ten countries if the capital account during 1988-94 had been zero. This counterfactual simulation uses the same basic approach described in section 3.3. Charts 5.3 and 5.4 compare the actual path of consumption in each of the ten countries to the path simulated by the multi-country model, once the capital account is set to zero for the 1988-94 period. Those charts indicate that, while the capital account had a statistically significant effect on consumption, setting the capital account to zero would not have altered substantially the basic trajectory of consumption in the ten countries. Recent capital inflows are estimated to have raised consumption by, at most, 1 percent of GDP, and usually by much less than that. As noted in reference to the Mexican consumption function (section 4.1), the coefficients on capital inflows in the multi-country equation may be biased upwards due to reverse causation, but this only strengthens our conclusion that capital inflows had small effects on consumption.

Charts 5.5 and 5.6 compare the actual and simulated paths of investment in the ten countries. While the impact of capital inflows on investment does appear to have been somewhat greater than on consumption, the results suggest that recent capital inflows generally raised investment by less than 2 percent of GDP. The exceptions are Thailand and Malaysia which experienced particularly large capital inflows during this period that appear to have raised investment by as much as 4 or 5 percent of GDP.

\section{Conclusions:}

This paper looks at the effect of capital flows on macroeconomic and financial variables in Mexico during the 1980s and 1990s and compares Mexico's experience with that of a cross-section of Pacific Basin developing countries. Based on the admittedly very rudimentary analysis we have performed so far, we draw the following tentative conclusions. 
First, both for Mexico and for the multi-country data set, we do find evidence of an independent effect of capital flows on monetary conditions and domestic demand, once other domestic conditions such as inflation and output growth are controlled for. We found that in Mexico, both reserve changes and capital inflows tended to lower interest rates and raise M2, although the results were more limited for our multi-country sample. Consumption was found to respond positively to capital inflows both in Mexico and in the multi-country sample. Investment also responded positively to capital inflows, but only in our multi-country sample.

Second, notwithstanding the evidence in support of linkages between capital inflows and macroeconomic outcomes, there was, at best, mixed evidence in favor of the expected channels of transmission linking the two sets of variables. Regressions applied to our Mexico sample indicate that the capital account affected M2 mainly by affecting the level of international reserves, as might conventionally be expected. However, in our counterfactual simulations, setting the capital account to zero during 1988-94 had a larger effect on interest rates and M2 than setting reserves to zero, in part because the capital account rose more strongly than reserve accumulation over much of this period. This suggests that the capital account may have influenced monetary conditions by some means other than boosting reserves in these years, perhaps by raising the money multiplier linking M2 to the monetary base.

Additionally, the expected channel through which capital flows influence consumption -- by raising bank deposits, bank credit, and hence spending -- was rejected by our data. When measures of M2 were added to our consumption equations, both for Mexico and the multi-country data set, their coefficients were estimated to be negative, suggesting that capital inflows must influence consumption by some means other than the bank deposit and credit channel.

Third, we found mixed evidence in favor of the view that different types of capital inflows exert different effects on macroeconomic performance. Foreign direct investment and portfolio investment had quite different estimated effects on consumption and investment, but the standard 
errors on those estimates were sufficiently large so that those effects were not statistically significantly different.

Fourth, based on the multi-country data set, we found mixed evidence that capital inflows affected investment and consumption differently in Latin American countries and in Asian countries. While estimated coefficients of response differed somewhat in the two sets of countries, these differences were not statistically significant, perhaps reflecting the imprecision of the estimates. Both results for Mexico and for the multi-country data set indicate positive effects of capital flows on consumption, but only the multi-country results support a positive effect of capital flows on investment. This is consistent with prior, impressionistic views that some, as yet unidentified, factors may have inhibited the response of Mexican investment to capital inflows.

Finally, and perhaps most importantly, notwithstanding our findings of statistically significant effects of capital inflows on macroeconomic performance, these inflows appear not to have altered substantially the basic trajectories of money, consumption, and investment in the recipient countries. Based on our Mexico data set, we find that even in the absence of capital inflows, the reduction in inflation and other factors would have led to strong growth in real M2 demand and in consumption in the 1988-94 period. Our results from the multi-country data set suggest that recent capital inflows raised consumption by, at most, 1 percent of GDP, and usually by much less than that. Finally, the results for investment indicate that, with the exception of Thailand and Malaysia, the effects of capital inflows were relatively modest as well.

In concluding, we should emphasize that our results, and particularly those based on the multi-country data set, are highly preliminary and represent no more than an initial exploration of correlations among the data. Should these results stand up to future investigation and testing, however, they will indicate that the role of capital inflows in laying the foundation for future macroeconomic imbalances and, perhaps, crises has been over-emphasized. In particular, rapid expansion of the monetary aggregates and consumption might have taken place even in the absence of 
heightened capital inflows. Quite possibly, these developments have been mistakenly attributed to capital inflows when they actually reflect the effects of other developments--exchange-rate based stabilization, financial liberalization, privatization--occurring simultaneously. 


\section{Bibliography}

Antzoulatos, Angelos A. "Capital Flows and Current Account Deficits in the 1990s: Why Did Latin American and East Asian Countries Respond Differently?". Federal Reserve Bank of New York, Research Paper \#9610, May 1996.

Calvo, Guillermo A., Leonardo Leiderman and Carmen Reinhart. "Capital Inflows and Real Exchange Rate Appreciation in Latin America: The Role of External Factors", IMF Staff Papers, Vol. 40, No. 1 (March 1993).

Calvo, Guillermo, Leonardo Leiderman, and Carmen M. Reinhart, "The Capital Inflows Problem: Concepts and Issues," Contemporary Economic Policy, Vol. 12 (1994).

Calvo, Guillermo A. and Enrique G. Mendoza. "Mexico's Balance-of-Payments Crisis: A Chronicle of Death Foretold", International Finance Discussion Paper No.545, Board of Governors of the Federal Reserve System, Washington D.C., February 1996.

Chuhan, Punam, Stijn Claessens, and Nlandu Mamingi, "Equity and Bond Flows to Latin America and Asia: The Role of Global and Country Factors," World Bank, Policy Research WPS 1160, July 1993.

Claessens, Stijn, Michael P. Dooley, and Andrew Warner, "Portfolio Capital Flows: Hot or Cold," The World Bank Economic Review, Vol. 9, No. 1, 153-174.

Copelman, Martina and Alejandro M. Werner, "The Monetary Transmission Mechanism in Mexico", unpublished manuscript, 1996.

Corbo, Vittorio and Leonardo Hernandez. "Macroeconomic Adjustment to Capital Flows", World Bank Policy Research Working Paper 1377, November 1994.

Fernandez-Arias, Eduardo and Peter J. Montiel. "The Surge in Capital Inflows to Developing Countries: Prospects and Policy Response", World Bank Policy Research Working Paper 1473, June 1995.

Gruben, William C. and Darryl McLeod. "Capital Flows, Savings, and Growth in the 1990s". Working paper, Federal Reserve Bank of Dallas, 1996.

Gunther, Jeffery W., Robert R. Moore, and Genie D. Short. "Mexican Banks and the 1994 Peso Crisis: The Importance of Initial Conditions". Working Paper, Federal Reserve Bank of Dallas, June 1996. Forthcoming in the North American Journal of Economics and Finance.

Kamin, Steven B. and John H. Rogers. "Monetary Policy in the End-Game to Exchange-Rate Based Stabilizations: The Case of Mexico", International Finance Discussion Paper No.540, Board of Governors of the Federal Reserve System, Washington D.C., February 1996.

Khan, Mohsin S. and Carmen M. Reinhart eds. "Capital Inflows in the APEC Region", IMF Occasional Paper 122, March 1995.

Koenig, Linda M. "Capital Inflows and Policy Responses in the ASIAN Region", IF Working Paper 96:25, April 1996. 
Rojas-Saurez, Liliana and Steven R. Weisbrod. "Financial Fragilities in Latin America: The 1980s and 1990s", IF Occasional Paper 132, October 1995.

Spiegel, Mark, "Sterilization of Capital Inflows through the Banking Sector: Evidence from Asia," Federal Reserve Bank of San Francisco Economic Review 1995, Number 3. 
Table 2.1 Mexican Investment, Savings, and Current Account Balance

(percent of GDP)

$\begin{array}{cccccc}\text { Year } & \begin{array}{c}\text { Private Fixed } \\ \text { Investment }\end{array} & \begin{array}{c}\text { Public Fixed } \\ \text { Investment }\end{array} & \begin{array}{c}\text { Total Fixed } \\ \text { Investment }\end{array} & \begin{array}{c}\text { Current } \\ \text { Account }\end{array} & \text { Savings } \\ 1985 & 12.5 & 6.6 & 19.10 & 0.4 & 19.50 \\ 1986 & 12.9 & 6.5 & 19.40 & -1.3 & 18.10 \\ 1987 & 12.9 & 5.6 & 18.50 & 2.8 & 21.30 \\ 1988 & 15.2 & 5.0 & 20.20 & -1.7 & 18.50 \\ 1989 & 13.3 & 4.8 & 18.10 & -2.9 & 15.20 \\ 1990 & 13.7 & 4.9 & 18.60 & -3.6 & 15.00 \\ 1991 & 14.9 & 4.6 & 19.50 & -5.2 & 14.30 \\ 1992 & 16.6 & 4.2 & 20.80 & -7.4 & 13.40 \\ 1993 & 16.4 & 4.0 & 20.40 & -6.4 & 14.00 \\ 1994 & 16.9 & 4.3 & 21.20 & -7.7 & 13.50\end{array}$


Table 3.1 Results for Mexican Interest Rate Reaction Function

Dependent variable: Change in interest rate

\begin{tabular}{|c|c|c|c|c|}
\hline & $\begin{array}{l}\text { Basic } \\
\text { Equation }\end{array}$ & $\begin{array}{l}\text { With Capital } \\
\text { Account }\end{array}$ & $\begin{array}{l}\text { With Change } \\
\text { in Reserves }\end{array}$ & With Both \\
\hline Constant & $\begin{array}{c}2.03 \\
(0.66)\end{array}$ & $\begin{array}{c}6.76 \\
(1.86)\end{array}$ & $\begin{array}{c}-0.27 \\
(-0.10)\end{array}$ & $\begin{array}{l}-1.25 \\
(-0.30)\end{array}$ \\
\hline Interest Rate $(-1)$ & $\begin{array}{c}-0.25 \\
(-2.28)\end{array}$ & $\begin{array}{c}-0.31 \\
(-2.72)\end{array}$ & $\begin{array}{c}-0.27 \\
(-2.67)\end{array}$ & $\begin{array}{l}-0.27 \\
(-2.47)\end{array}$ \\
\hline Inflation $(-1)$ & $\begin{array}{c}0.23 \\
(2.03)\end{array}$ & $\begin{array}{c}0.20 \\
(1.83)\end{array}$ & $\begin{array}{c}0.30 \\
(2.87)\end{array}$ & $\begin{array}{c}0.32 \\
(2.77)\end{array}$ \\
\hline Change in Inflation & $\begin{array}{c}0.71 \\
(7.52)\end{array}$ & $\begin{array}{c}0.73 \\
(8.03)\end{array}$ & $\begin{array}{c}0.80 \\
(9.67)\end{array}$ & $\begin{array}{c}0.80 \\
(9.32)\end{array}$ \\
\hline$\Delta$ Reserves $(-1)$ & & & $\begin{array}{c}-0.23 \\
(-3.86)\end{array}$ & $\begin{array}{c}-0.25 \\
(-2.95)\end{array}$ \\
\hline Change in $\Delta$ Reserves & & & $\begin{array}{l}-0.18 \\
(-3.54)\end{array}$ & $\begin{array}{c}-0.19 \\
(-2.61)\end{array}$ \\
\hline Capital Account (-1) & & $\begin{array}{l}-0.20 \\
(-2.35)\end{array}$ & & $\begin{array}{c}0.03 \\
(0.31)\end{array}$ \\
\hline Change in Capital Account & & $\begin{array}{c}-0.14 \\
(-2.27)\end{array}$ & & $\begin{array}{c}0.01 \\
(0.16)\end{array}$ \\
\hline Seasonal Q1 & $\begin{array}{c}-3.91 \\
(-1.18)\end{array}$ & $\begin{array}{l}-2.46 \\
(-0.77)\end{array}$ & $\begin{array}{c}-2.55 \\
(-0.90)\end{array}$ & $\begin{array}{l}-2.68 \\
(-0.91)\end{array}$ \\
\hline Seasonal Q2 & $\begin{array}{c}6.90 \\
(1.79)\end{array}$ & $\begin{array}{c}9.43 \\
(2.48)\end{array}$ & $\begin{array}{c}9.08 \\
(2.75)\end{array}$ & $\begin{array}{c}8.86 \\
(2.55)\end{array}$ \\
\hline Seasonal Q3 & $\begin{array}{c}2.11 \\
(0.63)\end{array}$ & $\begin{array}{c}3.10 \\
(0.97)\end{array}$ & $\begin{array}{c}3.35 \\
(1.19)\end{array}$ & $\begin{array}{c}3.23 \\
(1.11)\end{array}$ \\
\hline Adjusted R-squared & 0.57 & 0.62 & 0.70 & 0.68 \\
\hline Durbin-Watson Statistic & 2.07 & 2.09 & 2.27 & 2.30 \\
\hline
\end{tabular}


Table 3.2. Results for Mexican M2 Demand Function including Capital Account

Dependent variable: Change in log real M2

\begin{tabular}{|c|c|c|c|c|}
\hline & OLS & $\begin{array}{l}\text { OLS with } \\
\text { Capital } \\
\text { Account }\end{array}$ & $\begin{array}{l}\text { IV for interest } \\
\text { rate }\end{array}$ & $\begin{array}{l}\text { IV for interes } \\
\text { and capital } \\
\text { account }\end{array}$ \\
\hline Constant & $\begin{array}{l}-0.91 \\
(-3.49)\end{array}$ & $\begin{array}{c}-0.85 \\
(-3.27)\end{array}$ & $\begin{array}{c}-0.84 \\
(-3.12)\end{array}$ & $\begin{array}{c}-0.84 \\
(-3.09)\end{array}$ \\
\hline Interest Rate & $\begin{array}{l}-0.15 \\
(-5.88)\end{array}$ & $\begin{array}{l}-0.13 \\
(-4.25)\end{array}$ & $\begin{array}{l}-0.12 \\
(-4.08)\end{array}$ & $\begin{array}{l}-0.13 \\
(-4.01)\end{array}$ \\
\hline $\begin{array}{l}\text { Four-Quarter Interest Rate } \\
\text { Change }\end{array}$ & $\begin{array}{c}0.10 \\
(3.07)\end{array}$ & $\begin{array}{c}0.09 \\
(2.51)\end{array}$ & $\begin{array}{c}0.08 \\
(2.05)\end{array}$ & $\begin{array}{c}0.08 \\
(1.92)\end{array}$ \\
\hline Log (Real M2/GDP)(-1) & $\begin{array}{l}-0.15 \\
(-3.68)\end{array}$ & $\begin{array}{l}-0.14 \\
(-3.39)\end{array}$ & $\begin{array}{l}-0.14 \\
(-3.23)\end{array}$ & $\begin{array}{l}-0.14 \\
(-3.21)\end{array}$ \\
\hline Capital Account & & $\begin{array}{c}0.16 \\
(1.41)\end{array}$ & $\begin{array}{c}0.19 \\
(1.67)\end{array}$ & $\begin{array}{c}0.14 \\
(0.97)\end{array}$ \\
\hline Adjusted R-squared & 0.42 & 0.44 & & \\
\hline Durbin-Watson Statistic & 2.20 & 2.36 & 2.07 & 2.11 \\
\hline
\end{tabular}


Table 3.3. Results for Mexican M2 Demand Function including Change in Reserves

Dependent variable: Change in log real M2

$\begin{array}{lcccc} & \text { OLS } & \begin{array}{l}\text { OLS with } \\ \text { change in } \\ \text { reserves }\end{array} & \begin{array}{l}\text { IV for interest } \\ \text { rate }\end{array} & \begin{array}{l}\text { IV for interest } \\ \text { rate and } \\ \text { change in } \\ \text { reserves }\end{array} \\ \text { Constant } & -0.91 & -0.88 & -0.84 & -0.82 \\ \text { Interest Rate } & (-3.49) & (-3.45) & (-3.25) & (-3.17) \\ \text { Annual Interest Rate } & -0.15 & -0.15 & -0.15 & -0.16 \\ \text { Change } & (-5.88) & (-6.06) & (-6.17) & (-6.25) \\ \text { Log (Real M2/GDP)(-1) } & -0.10 & 0.09 & 0.06 & 0.05 \\ \text { Change in Reserves } & (3.07) & (2.74) & (1.73) & (1.41) \\ & -0.15 & -0.15 & -0.14 & -0.14 \\ \text { Adjusted R-squared } & (-3.68) & (-3.65) & (-3.45) & (-3.38) \\ \text { Durbin-Watson Statistic } & 2.20 & 0.14 & 0.21 & 0.28 \\ & & (1.63) & (2.18) & (2.30) \\ & & 0.45 & & \\ & & 2.52 & 2.40 & 2.21\end{array}$


Table 4.1 Results for Mexican Consumption

Dependent variable: Log Change in Real Consumption

\begin{tabular}{|c|c|c|c|c|c|c|}
\hline & $\begin{array}{l}\text { Basic } \\
\text { Equation }\end{array}$ & $\begin{array}{l}\text { With } \\
\text { Capital } \\
\text { Account }\end{array}$ & $\begin{array}{l}\text { With } \\
\text { FDI }\end{array}$ & $\begin{array}{l}\text { With } \\
\text { Portfolio } \\
\text { Inflows }\end{array}$ & $\begin{array}{l}\text { With } \\
\text { Capital } \\
\text { Account } \\
\text { and FDI }\end{array}$ & $\begin{array}{l}\text { Capital } \\
\text { Account } \\
\text { and } \\
\text { Portfolio }\end{array}$ \\
\hline Constant & $\begin{array}{c}1.17 \\
(2.37)\end{array}$ & $\begin{array}{c}2.02 \\
(3.02)\end{array}$ & $\begin{array}{c}1.26 \\
(2.43)\end{array}$ & $\begin{array}{c}1.93 \\
(2.63)\end{array}$ & $\begin{array}{c}1.99 \\
(2.91)\end{array}$ & $\begin{array}{c}2.26 \\
(2.90)\end{array}$ \\
\hline$\Delta$ Real Interest Rate & $\begin{array}{c}0.01 \\
(0.51)\end{array}$ & $\begin{array}{c}0.01 \\
(0.51)\end{array}$ & $\begin{array}{c}0.01 \\
(0.43)\end{array}$ & $\begin{array}{c}0.01 \\
(0.42)\end{array}$ & $\begin{array}{c}0.01 \\
(0.48)\end{array}$ & $\begin{array}{c}0.12 \\
(0.46)\end{array}$ \\
\hline$\Delta$ Log Real GDP & $\begin{array}{c}0.88 \\
(4.99)\end{array}$ & $\begin{array}{c}0.85 \\
(4.80)\end{array}$ & $\begin{array}{c}0.85 \\
(4.62)\end{array}$ & $\begin{array}{c}0.83 \\
(4.54)\end{array}$ & $\begin{array}{c}0.84 \\
(4.57)\end{array}$ & $\begin{array}{c}0.83 \\
(4.55)\end{array}$ \\
\hline Real Interest Rate $(-1)$ & $\begin{array}{c}0.02 \\
(0.85)\end{array}$ & $\begin{array}{c}0.01 \\
(0.69)\end{array}$ & $\begin{array}{c}0.01 \\
(0.64)\end{array}$ & $\begin{array}{c}0.02 \\
(0.85)\end{array}$ & $\begin{array}{c}0.02 \\
(0.70)\end{array}$ & $\begin{array}{c}0.17 \\
(0.78)\end{array}$ \\
\hline Log Real GDP (-1) & $\begin{array}{c}0.42 \\
(2.47)\end{array}$ & $\begin{array}{c}0.51 \\
(2.88)\end{array}$ & $\begin{array}{c}0.42 \\
(2.42)\end{array}$ & $\begin{array}{c}0.41 \\
(2.23)\end{array}$ & $\begin{array}{c}0.50 \\
(2.80)\end{array}$ & $\begin{array}{c}0.48 \\
(2.48)\end{array}$ \\
\hline Log Real Consumption (-1) & $\begin{array}{c}-0.35 \\
(-2.61)\end{array}$ & $\begin{array}{c}-0.47 \\
(-3.17)\end{array}$ & $\begin{array}{c}-0.36 \\
(-2.59)\end{array}$ & $\begin{array}{c}-0.40 \\
(-2.81)\end{array}$ & $\begin{array}{c}-0.46 \\
(-3.07)\end{array}$ & $\begin{array}{c}-0.47 \\
(-3.06)\end{array}$ \\
\hline$\Delta$ Log Real Consumption(-1) & $\begin{array}{c}0.07 \\
(0.57)\end{array}$ & $\begin{array}{c}0.12 \\
(0.93)\end{array}$ & $\begin{array}{c}0.08 \\
(0.63)\end{array}$ & $\begin{array}{c}0.11 \\
(0.81)\end{array}$ & $\begin{array}{c}0.12 \\
(0.91)\end{array}$ & $\begin{array}{c}0.13 \\
(0.94)\end{array}$ \\
\hline$\Delta$ Capital Account & & $\begin{array}{c}0.13 \\
(1.73)\end{array}$ & & & $\begin{array}{c}0.23 \\
(1.45)\end{array}$ & $\begin{array}{c}0.21 \\
(1.22)\end{array}$ \\
\hline Capital Account (-1) & & $\begin{array}{c}0.39 \\
(1.83)\end{array}$ & & & $\begin{array}{c}0.36 \\
(1.62)\end{array}$ & $\begin{array}{c}0.32 \\
(1.29)\end{array}$ \\
\hline$\Delta$ FDI & & & $\begin{array}{c}0.12 \\
(0.16)\end{array}$ & & $\begin{array}{c}0.16 \\
(0.22)\end{array}$ & \\
\hline FDI $(-1)$ & & & $\begin{array}{c}-0.63 \\
(-0.69)\end{array}$ & & $\begin{array}{c}-0.26 \\
(-0.28)\end{array}$ & \\
\hline$\Delta$ Portfolio Investment & & & & $\begin{array}{c}0.36 \\
(1.03)\end{array}$ & & $\begin{array}{c}0.16 \\
(0.41)\end{array}$ \\
\hline Portfolio Investment $(-1)$ & & & & $\begin{array}{c}0.61 \\
(1.32)\end{array}$ & & $\begin{array}{c}0.33 \\
(0.64)\end{array}$ \\
\hline Adj. R-squared & 0.35 & 0.35 & 0.31 & 0.33 & 0.32 & 0.32 \\
\hline Durbin-Watson Statistic & 2.08 & 2.06 & 2.04 & 2.04 & 2.06 & 2.05 \\
\hline
\end{tabular}


Table 4.2. Results for Mexican Consumption including Real M2

Dependent variable: Log Change in Real Consumption

\begin{tabular}{|c|c|c|c|c|}
\hline & $\begin{array}{l}\text { Basic } \\
\text { Equation }\end{array}$ & $\begin{array}{l}\text { With Capital } \\
\text { Account }\end{array}$ & With FDI & $\begin{array}{l}\text { With Portfolio } \\
\text { Inflows }\end{array}$ \\
\hline Constant & $\begin{array}{c}0.80 \\
(1.20)\end{array}$ & $\begin{array}{l}1.45 \\
(2.02)\end{array}$ & $\begin{array}{c}0.75 \\
(1.13)\end{array}$ & $\begin{array}{c}1.56 \\
(1.88)\end{array}$ \\
\hline$\Delta$ Real Interest Rate & $\begin{array}{c}-0.00 \\
(-0.04)\end{array}$ & $\begin{array}{c}0.00 \\
(0.02)\end{array}$ & $\begin{array}{c}-0.00 \\
(-0.10)\end{array}$ & $\begin{array}{l}-0.00 \\
(-0.15)\end{array}$ \\
\hline$\Delta \log$ in Real GDP & $\begin{array}{c}0.91 \\
(5.25)\end{array}$ & $\begin{array}{c}0.90 \\
(5.22)\end{array}$ & $\begin{array}{c}0.92 \\
(5.12)\end{array}$ & $\begin{array}{c}0.86 \\
(4.83)\end{array}$ \\
\hline Real Interest Rate (-1) & $\begin{array}{c}-0.01 \\
(-0.35)\end{array}$ & $\begin{array}{l}-0.00 \\
(-0.39)\end{array}$ & $\begin{array}{c}-0.01 \\
(-0.59)\end{array}$ & $\begin{array}{l}-0.00 \\
(-0.22)\end{array}$ \\
\hline Log Real GDP (-1) & $\begin{array}{c}0.60 \\
(3.18)\end{array}$ & $\begin{array}{c}0.70 \\
(3.64)\end{array}$ & $\begin{array}{c}0.66 \\
(3.35)\end{array}$ & $\begin{array}{c}0.57 \\
(2.88)\end{array}$ \\
\hline Log Real Consumption (-1) & $\begin{array}{c}-0.43 \\
(-3.05)\end{array}$ & $\begin{array}{c}-0.54 \\
(-3.63)\end{array}$ & $\begin{array}{l}-0.46 \\
(-3.17)\end{array}$ & $\begin{array}{c}-0.46 \\
(-3.13)\end{array}$ \\
\hline$\Delta$ Log Real Consumption(-1) & $\begin{array}{c}0.02 \\
(0.19)\end{array}$ & $\begin{array}{c}0.06 \\
(0.50)\end{array}$ & $\begin{array}{c}0.03 \\
(0.26)\end{array}$ & $\begin{array}{c}0.04 \\
(0.32)\end{array}$ \\
\hline$\Delta$ Capital Account & & $\begin{array}{c}0.27 \\
(1.78)\end{array}$ & & \\
\hline Capital Account (-1) & & $\begin{array}{c}0.48 \\
(2.17)\end{array}$ & & \\
\hline$\Delta$ FDI & & & $\begin{array}{c}-0.32 \\
(-0.44)\end{array}$ & \\
\hline FDI $(-1)$ & & & $\begin{array}{l}-1.37 \\
(-1.47)\end{array}$ & \\
\hline$\Delta$ Portfolio Investment & & & & $\begin{array}{c}0.23 \\
(0.67)\end{array}$ \\
\hline Portfolio Investment $(-1)$ & & & & $\begin{array}{c}0.70 \\
(1.55)\end{array}$ \\
\hline$\Delta$ Log Real M2 & $\begin{array}{c}0.05 \\
(0.72)\end{array}$ & $\begin{array}{c}-0.05 \\
(-2.17)\end{array}$ & $\begin{array}{c}0.04 \\
(0.55)\end{array}$ & $\begin{array}{c}0.04 \\
(0.59)\end{array}$ \\
\hline Log Real M2 (-1) & $\begin{array}{l}-0.04 \\
(-1.76)\end{array}$ & $\begin{array}{l}-0.01 \\
(-0.15)\end{array}$ & $\begin{array}{l}-0.05 \\
(-2.14)\end{array}$ & $\begin{array}{l}-0.04 \\
(-1.80)\end{array}$ \\
\hline
\end{tabular}


Table 4.3 Results for Mexican Investment

Dependent variable: Log Change in Real Investment

\begin{tabular}{|c|c|c|c|c|}
\hline & OLS & $\begin{array}{l}\text { OLS with } \\
\text { Capital } \\
\text { Account }\end{array}$ & $\begin{array}{l}\text { OLS with } \\
\text { FDI }\end{array}$ & $\begin{array}{l}\text { OLS with } \\
\text { Portfolio Inflows }\end{array}$ \\
\hline Constant & $\begin{array}{l}-15.62 \\
(-4.11)\end{array}$ & $\begin{array}{l}-16.44 \\
(-3.75)\end{array}$ & $\begin{array}{l}-15.39 \\
(-3.95)\end{array}$ & $\begin{array}{l}-16.32 \\
(-3.95)\end{array}$ \\
\hline Change in Real Interest Rate & $\begin{array}{c}0.08 \\
(1.11)\end{array}$ & $\begin{array}{c}0.08 \\
(1.09)\end{array}$ & $\begin{array}{c}0.07 \\
(1.03)\end{array}$ & $\begin{array}{c}0.08 \\
(1.18)\end{array}$ \\
\hline Log Change in Real GDP & $\begin{array}{c}2.70 \\
(5.39)\end{array}$ & $\begin{array}{c}2.75 \\
(5.22)\end{array}$ & $\begin{array}{c}2.57 \\
(5.03)\end{array}$ & $\begin{array}{c}2.80 \\
(5.42)\end{array}$ \\
\hline Real Interest Rate (-1) & $\begin{array}{c}-0.00 \\
(-0.05)\end{array}$ & $\begin{array}{c}0.00 \\
(0.03)\end{array}$ & $\begin{array}{c}0.00 \\
(0.11)\end{array}$ & $\begin{array}{c}-0.01 \\
(-0.20)\end{array}$ \\
\hline Log Real GDP (-1) & $\begin{array}{c}2.33 \\
(4.16)\end{array}$ & $\begin{array}{c}2.44 \\
(3.81)\end{array}$ & $\begin{array}{c}2.30 \\
(3.99)\end{array}$ & $\begin{array}{c}2.39 \\
(3.92)\end{array}$ \\
\hline Log Real Investment (-1) & $\begin{array}{l}-0.66 \\
(-4.16)\end{array}$ & $\begin{array}{l}-0.68 \\
(-3.90)\end{array}$ & $\begin{array}{l}-0.66 \\
(-3.99)\end{array}$ & $\begin{array}{l}-0.62 \\
(-3.45)\end{array}$ \\
\hline $\begin{array}{l}\text { Log Change in Real } \\
\text { Investment }(-1)\end{array}$ & $\begin{array}{c}-0.09 \\
(-0.91)\end{array}$ & $\begin{array}{l}-0.07 \\
(-0.53)\end{array}$ & $\begin{array}{l}-0.04 \\
(-0.33)\end{array}$ & $\begin{array}{l}-0.11 \\
(-0.92)\end{array}$ \\
\hline$\Delta$ Capital Account & & $\begin{array}{l}-0.09 \\
(-0.23)\end{array}$ & & \\
\hline Capital Account (-1) & & $\begin{array}{l}-0.31 \\
(-0.52)\end{array}$ & & \\
\hline$\Delta$ FDI & & & $\begin{array}{c}2.21 \\
(1.09)\end{array}$ & \\
\hline FDI $(-1)$ & & & $\begin{array}{l}-0.55 \\
(-0.22)\end{array}$ & \\
\hline$\Delta$ Portfolio Investment & & & & $\begin{array}{c}0.17 \\
(0.17)\end{array}$ \\
\hline Portfolio Investment $(-1)$ & & & & $\begin{array}{l}-1.52 \\
(-1.11)\end{array}$ \\
\hline Adjusted R-squared & 0.51 & 0.49 & 0.53 & 0.50 \\
\hline Durbin-Watson Statistic & 1.93 & 1.97 & 1.90 & 2.03 \\
\hline
\end{tabular}


Table 5.1 Multi-Country Results for Interest Rate Reaction Function

Dependent variable: Change in interest rate

$\begin{array}{lcccc} & \text { Basic } & \text { With Capital } & \text { With Change } & \text { With Both } \\ & \text { Equation } & \text { Account } & \text { in Reserves } & \\ \text { Constant } & 3.28 & 3.47 & 3.36 & 3.43 \\ & (2.27) & (2.17) & (2.51) & (2.35) \\ \text { Interest Rate (-1) } & -0.50 & -0.51 & -0.51 & -0.49 \\ & (-5.36) & (-4.94) & (-5.55) & (-5.04) \\ \text { Inflation (-1) } & 0.47 & 0.46 & 0.48 & 0.45 \\ & (4.96) & (4.61) & (5.42) & (4.88) \\ \text { Change in Inflation } & 0.59 & 0.58 & 0.61 & 0.59 \\ & (9.14) & (8.59) & (10.00) & (9.50) \\ \text { Change in Reserves (-1) } & & & -9.26 & -10.44 \\ & & & (-1.29) & (-1.44) \\ \text { Change in } & & & 7.89 & 8.16 \\ \text { Change in Reserves } & & & (1.57) & (1.61) \\ \text { Capital Account (-1) } & & -1.78 & & -2.94 \\ \text { Change in Capital Account } & & (-0.35) & & (-0.64) \\ & & -4.06 & & -5.94 \\ & & (-0.74) & & (-1.18)\end{array}$


Table 5.2. Multi-Country Results for M2 Demand Function

Dependent variable: Log real M2

$\begin{array}{lccccc} & \text { OLS } & \begin{array}{l}\text { OLS with } \\ \text { Capital } \\ \text { Account }\end{array} & \begin{array}{l}\text { IV for } \\ \text { interest rate }\end{array} & \begin{array}{l}\text { OLS with } \\ \text { change in } \\ \text { reserves }\end{array} & \begin{array}{l}\text { IV for } \\ \text { interest rate }\end{array} \\ \text { Constant } & -4.74 & -4.73 & -4.24 & -3.25 & -2.80 \\ \text { Interest Rate } & (-4.28) & (-4.27) & (-4.02) & (-3.17) & (-3.07) \\ & -0.43 & -0.36 & -0.69 & -0.61 & -0.84 \\ \text { Log Real GDP } & (-3.27) & (-2.48) & (-4.77) & (-4.96) & (-7.68) \\ \text { Log Real M2 (-1) } & 0.60 & 0.59 & 0.55 & 0.45 & 0.40 \\ & (4.78) & (4.70) & (4.57) & (3.88) & (3.93) \\ \text { Capital Account } & 0.64 & 0.65 & 0.66 & 0.69 & 0.71 \\ \text { Change in Reserves } & (8.74) & (8.77) & (9.35) & (10.54) & (11.98) \\ & & 0.12 & -0.07 & & \\ & & (0.96) & (-0.01) & & 0.69 \\ & & & & 0.66 & (5.89)\end{array}$


Table 5.3 Multi-Country Results for Consumption

Dependent variable: Log Real Consumption

$\begin{array}{llllll}\text { Basic } & \text { With } & \text { With } & \text { With } & \text { With } & \text { With } \\ \text { Equation } & \text { Capital } & \text { FDI } & \text { Portfolio } & \text { Capital } & \text { Capital } \\ & \text { Account } & & \text { Inflows } & \text { Account } & \text { Account } \\ & & & & \text { and FDI } & \text { and } \\ & & & & & \text { Portfolio } \\ & & & & & \text { Inflows }\end{array}$

$\begin{array}{lcccccc}\text { Constant } & 0.03 & 0.08 & 0.06 & 0.04 & 0.08 & 0.07 \\ & (0.24) & (0.76) & (0.51) & (0.34) & (0.67) & (0.60) \\ \text { Log Real Consumption (-1) } & 0.75 & 0.73 & 0.74 & 0.73 & 0.73 & 0.70 \\ & (12.25) & (12.07) & (11.74) & (10.92) & (11.85) & (10.39) \\ \text { Log Real GDP } & 0.23 & 0.24 & 0.23 & 0.24 & 0.24 & 0.27 \\ & (4.37) & (4.68) & (4.40) & (4.08) & (4.63) & (4.50) \\ \Delta \text { Log Real GDP } & 0.55 & 0.55 & 0.54 & 0.58 & 0.55 & 0.56 \\ & (7.83) & (7.97) & (7.45) & (7.78) & (7.79) & (7.59) \\ \text { Capital Account/GDP } & & 0.20 & & & 0.21 & 0.21 \\ & & (2.83) & & & (2.72) & (2.27) \\ \text { FDI/GDP } & & & 0.26 & & -0.04 & \\ & & & (0.75) & & (-0.13) & \\ \text { Portfolio Inflows/GDP } & & & & 0.10 & & -0.02 \\ & & & & (0.56) & & (-0.09)\end{array}$


Table 5.4 Multi-Country Results for Consumption including Real M2

Dependent variable: Log Real Consumption

$\begin{array}{lcccc} & \begin{array}{l}\text { Basic } \\ \text { Equation }\end{array} & \text { With Capital } & \text { With FDI } & \text { With Portfolio } \\ & -0.10 & -0.03 & -0.06 & -0.10 \\ \text { Constant } & (-0.89) & (-0.30) & (-0.50) & (-0.90) \\ & 0.70 & 0.67 & 0.69 & 0.66 \\ \text { Log Real Consumption (-1) } & (11.87) & (11.78) & (11.39) & (10.01) \\ \text { Log Real GDP } & 0.33 & 0.35 & 0.34 & 0.37 \\ & (5.97) & (6.50) & (6.03) & (5.80) \\ \Delta \text { Log Real GDP } & 0.51 & 0.51 & 0.50 & 0.53 \\ \text { Capital Account/GDP } & (7.52) & (7.80) & (7.20) & (7.38) \\ \text { FDI/GDP } & & 0.22 & & \\ \text { Portfolio Inflows/GDP } & & (3.39) & & \\ \text { Log Real M2 } & & & 0.28 & \\ & & & (0.89) & (1.21) \\ & & & & -0.05 \\ & -0.05 & -0.05 & -0.05 & (-4.37)\end{array}$


Table 5.5 Multi-Country Results for Investment

Dependent variable: Log Real Investment

$\begin{array}{llllll}\text { Basic } & \text { With } & \text { With FDI } & \text { With } & \text { With } & \text { With } \\ \text { Equation } & \text { Capital } & & \text { Portfolio } & \text { Capital } & \text { Capital } \\ & \text { Account } & & \text { Inflows } & \text { Account } & \text { Account } \\ & & & \text { and FDI } & \text { and } \\ & & & & \text { Portfolio } \\ & & & & \text { Inflows }\end{array}$

$\begin{array}{lcccccc}\text { Constant } & -1.37 & -1.59 & -1.18 & -1.27 & -1.49 & -1.53 \\ & (-4.29) & (-5.32) & (-3.63) & (-4.11) & (-4.73) & (-5.17) \\ \text { Log Real Investment (-1) } & 0.66 & 0.55 & 0.65 & 0.65 & 0.56 & 0.56 \\ & (11.52) & (9.73) & (11.70) & (10.94) & (9.78) & (9.15) \\ \text { Log Real GDP } & 0.47 & 0.59 & 0.45 & 0.46 & 0.57 & 0.58 \\ & (5.61) & (7.24) & (5.37) & (5.49) & (6.78) & (6.94) \\ \Delta \text { Log Real GDP } & 1.09 & 0.97 & 1.04 & 0.98 & 0.97 & 0.82 \\ & (6.61) & (6.31) & (6.43) & (5.87) & (6.28) & (5.16) \\ \text { Capital Account/GDP } & & 0.84 & & & 0.77 & 0.91 \\ & & (4.79) & & & (4.12) & (4.20) \\ \text { FDI/GDP } & & & 1.98 & & 0.82 & \\ & & & (2.51) & & (1.03) & \\ \text { Portfolio Inflows/GDP } & & & & 0.55 & & 0.01 \\ & & & & (1.32) & & (0.02)\end{array}$


Table 5.6 Latin America versus Asia

$\underline{\text { Coefficients from Consumption Equation }}$

Capital Account $\quad$ FDI Portfolio Inflows
All Countries
0.20
0.26
0.10
Asia *
0.14
0.20
0.21
Latin America *
0.24
0.90
0.06
T-Statistic on
$(-0.37)$
Interaction Dummy

Coefficients from Investment Equation

Capital Account FDI Portfolio Inflows
All Countries
0.84
1.98
0.55
Asia *
0.87
0.37
Latin America *
0.82
$-0.18$
0.63
T-Statistic on
$(-0.75)$
Interaction Dummy
* In equations with region-specific coefficients, the interaction dummy, D times the capital flow variable, was added to the equation along with the capital flow measure itself; $D=0$ for Asian country, $\mathrm{D}=1$ for Latin American country. The coefficient for Asian countries is the coefficient on the capital flow measure alone. The coefficient for Latin American countries is the coefficient on the capital flow measure plus the coefficient on the interaction dummy. 


\section{Mexican Net Capital Inflows}

Capital Account and Change in Reserves

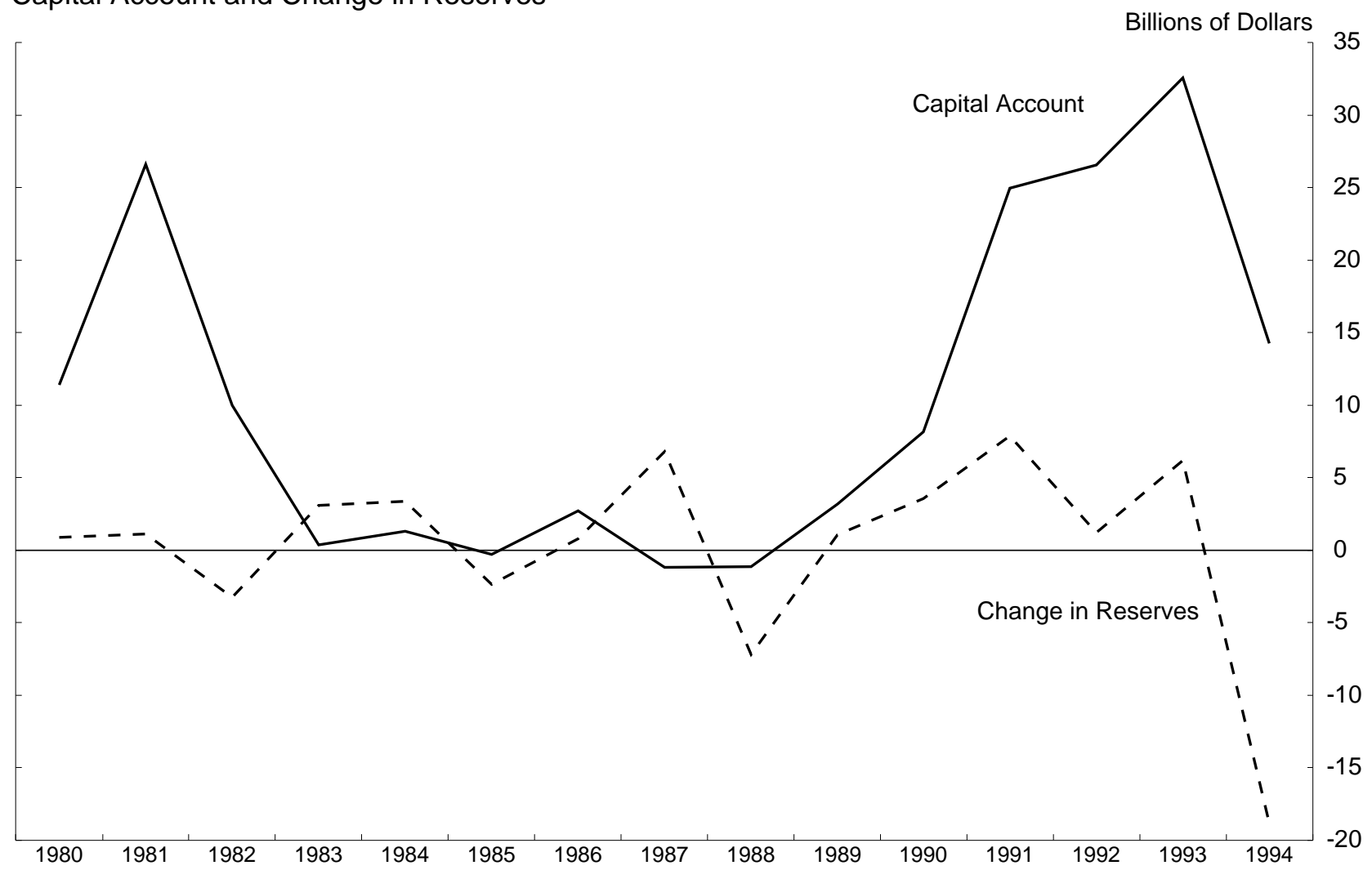

Portfolio Investment and Foreign Direct Investment

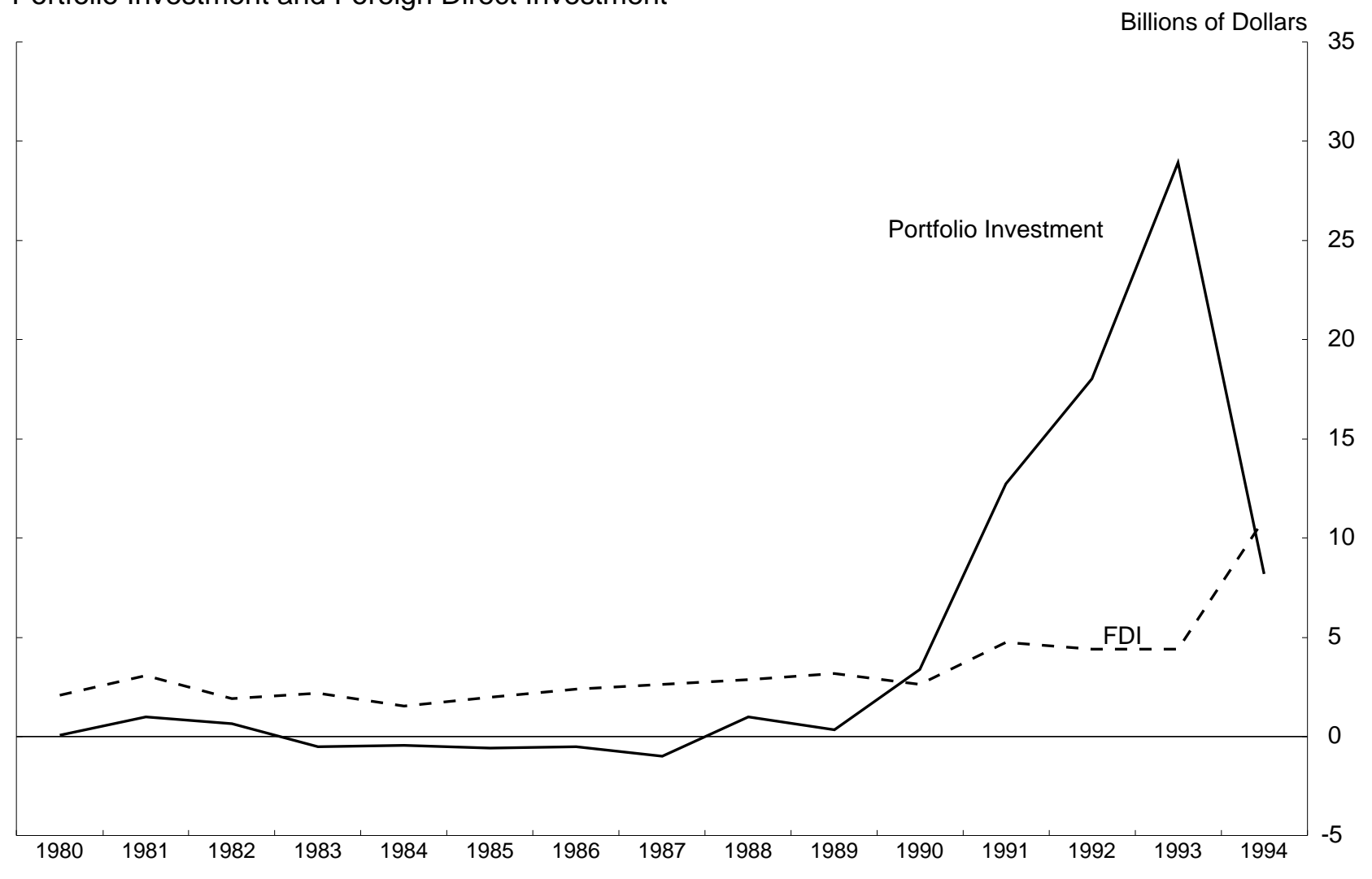




\section{Mexican Economic Indicators}

\section{Exchange Rate}

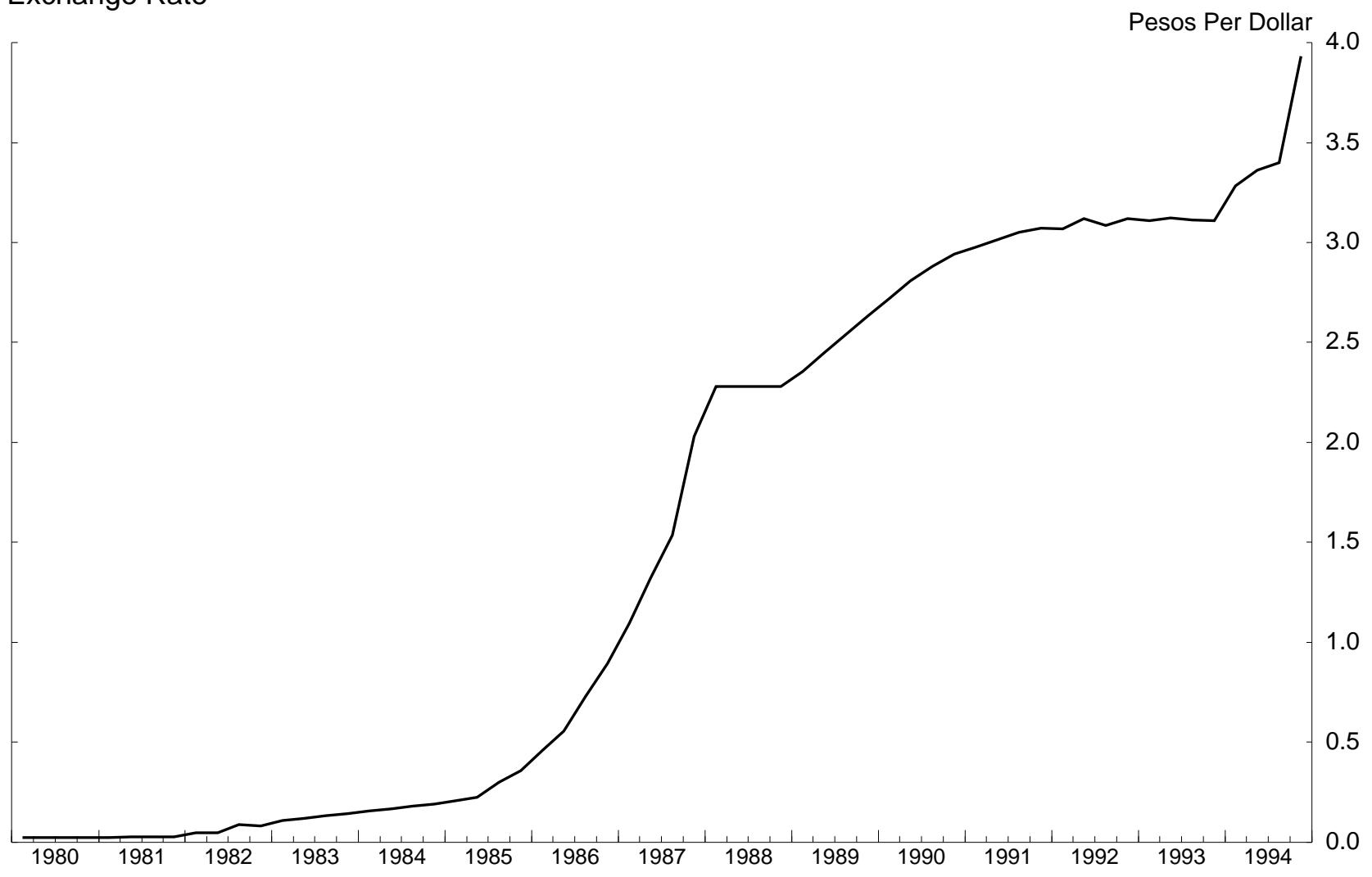

Inflation and Real GDP

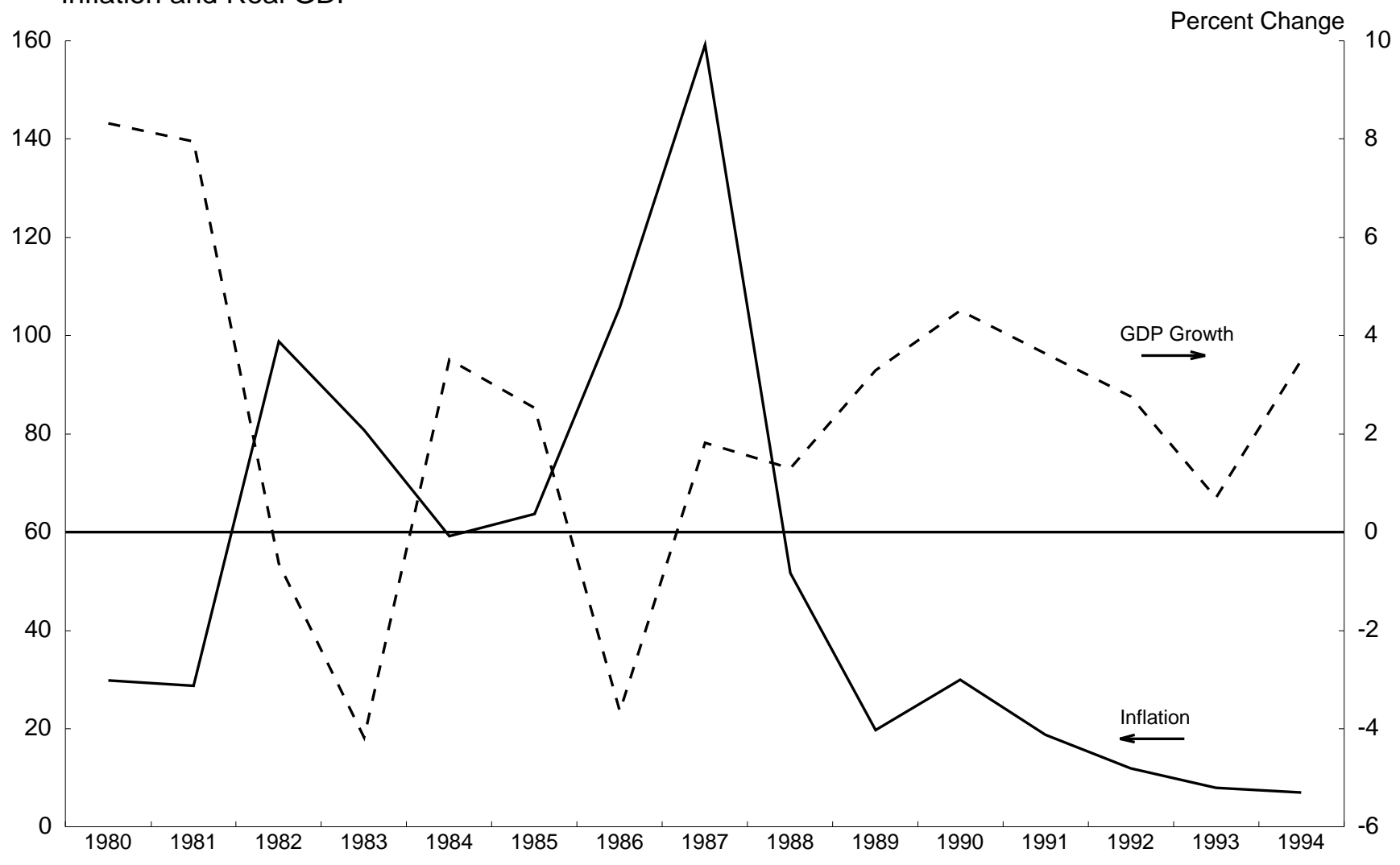


Chart 2.3

\section{Mexican Financial Indicators}

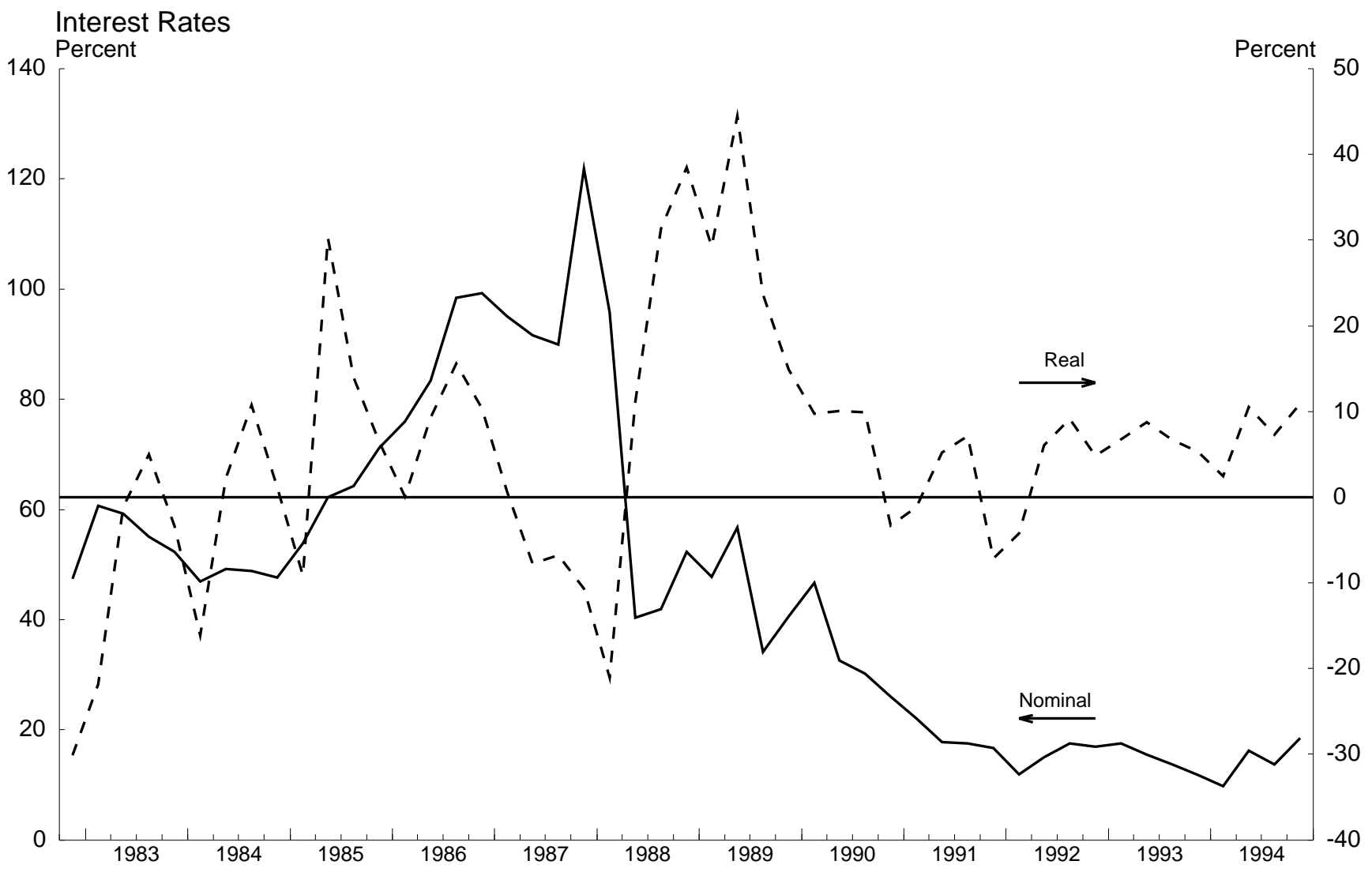

M2, Monetary Base, and Bank Loans

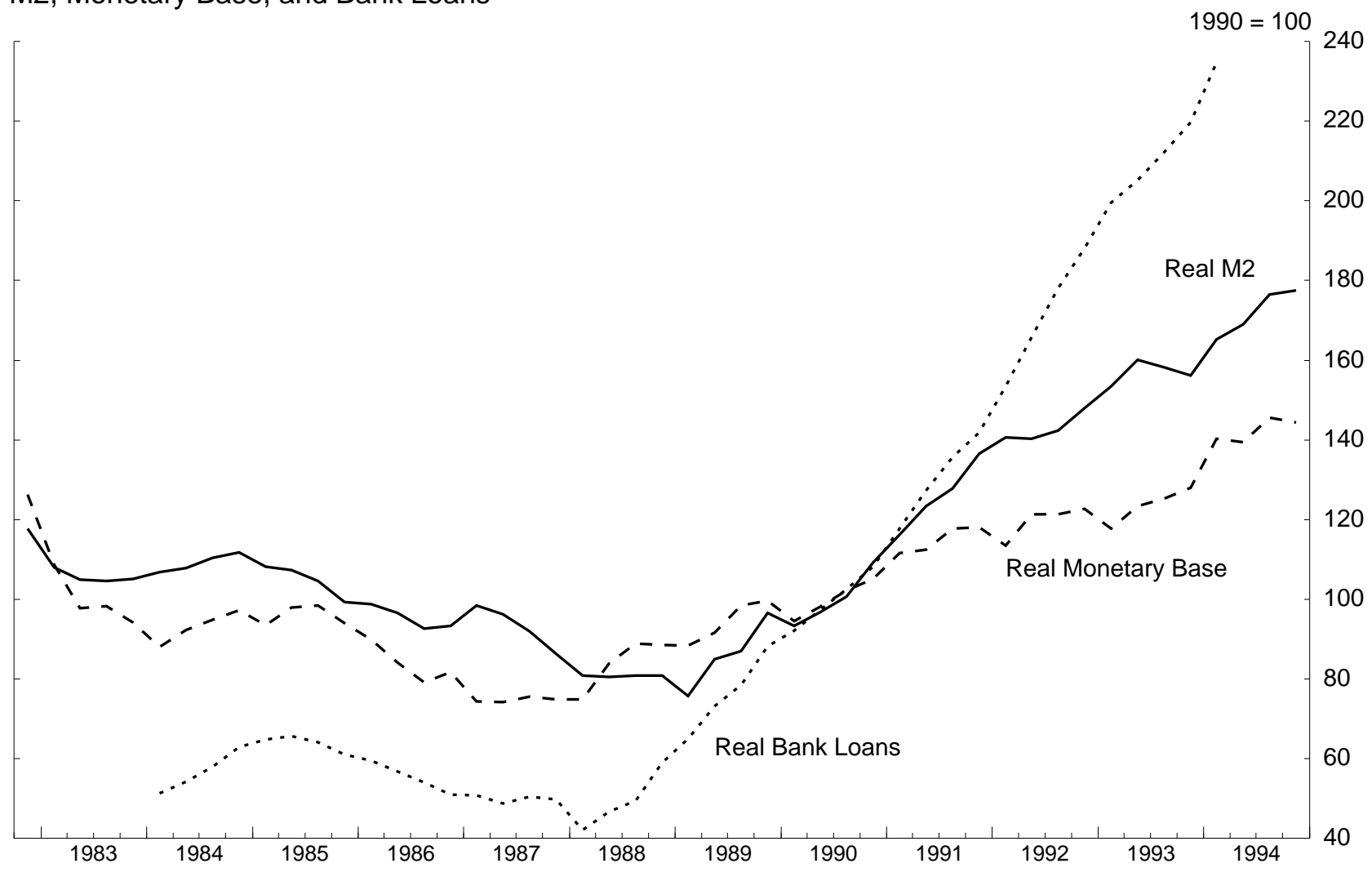




\section{Mexican Interest Rate Simulations}

Actual and Simulated Interest Rates

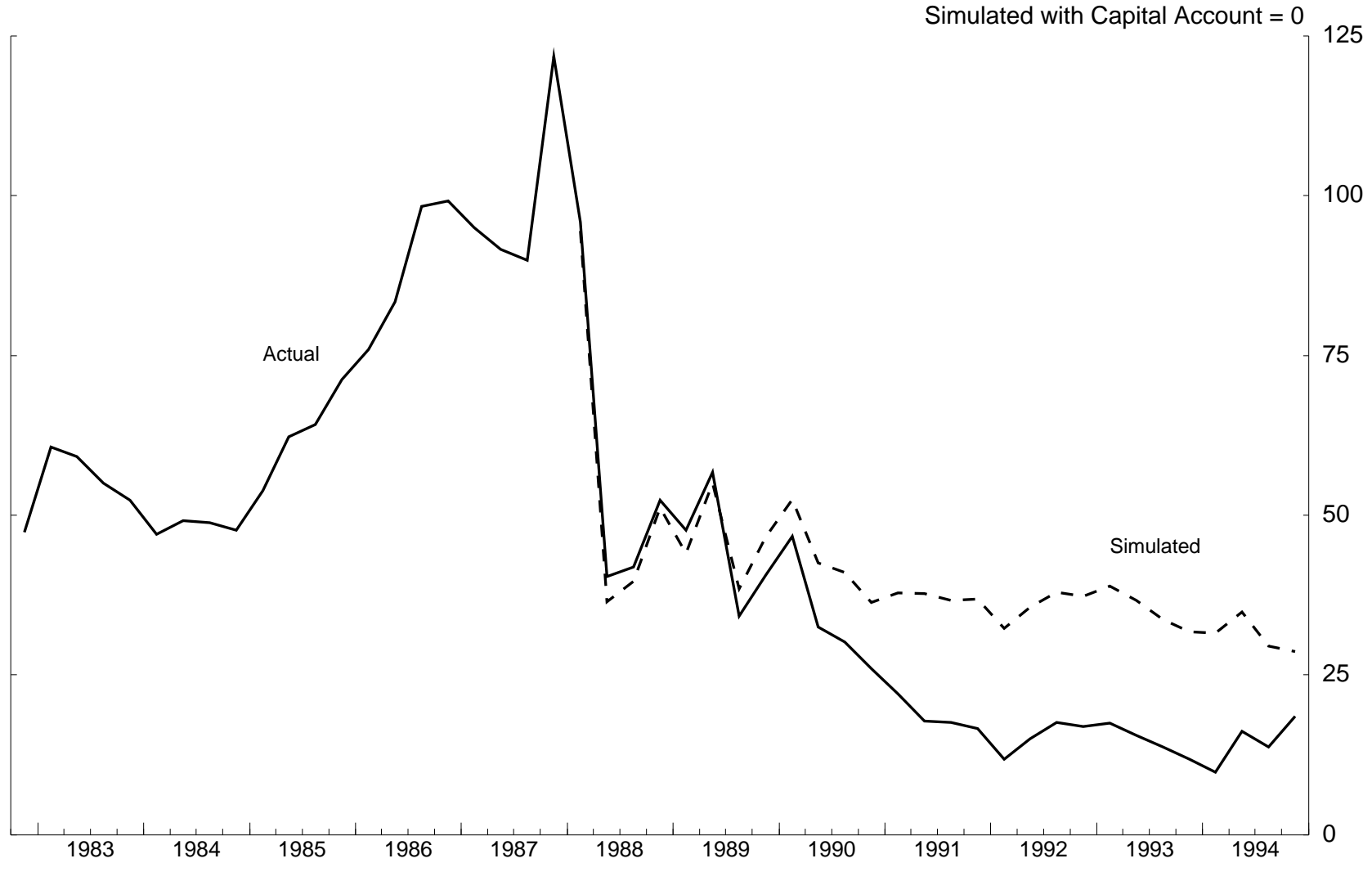

Actual and Simulated Interest Rates

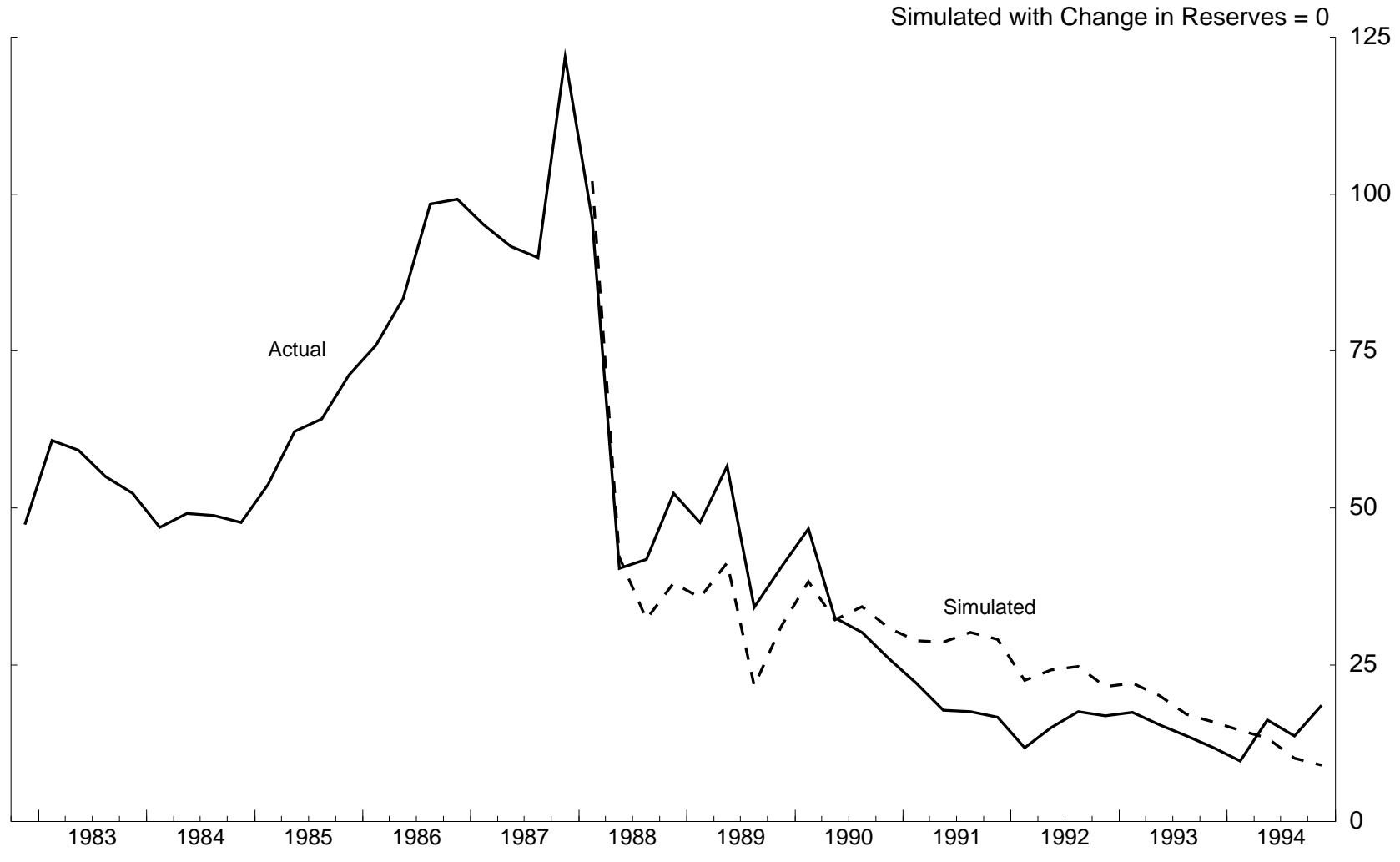




\section{Mexican Real M2 Simulations}

Actual and Simulated Log of Real M2

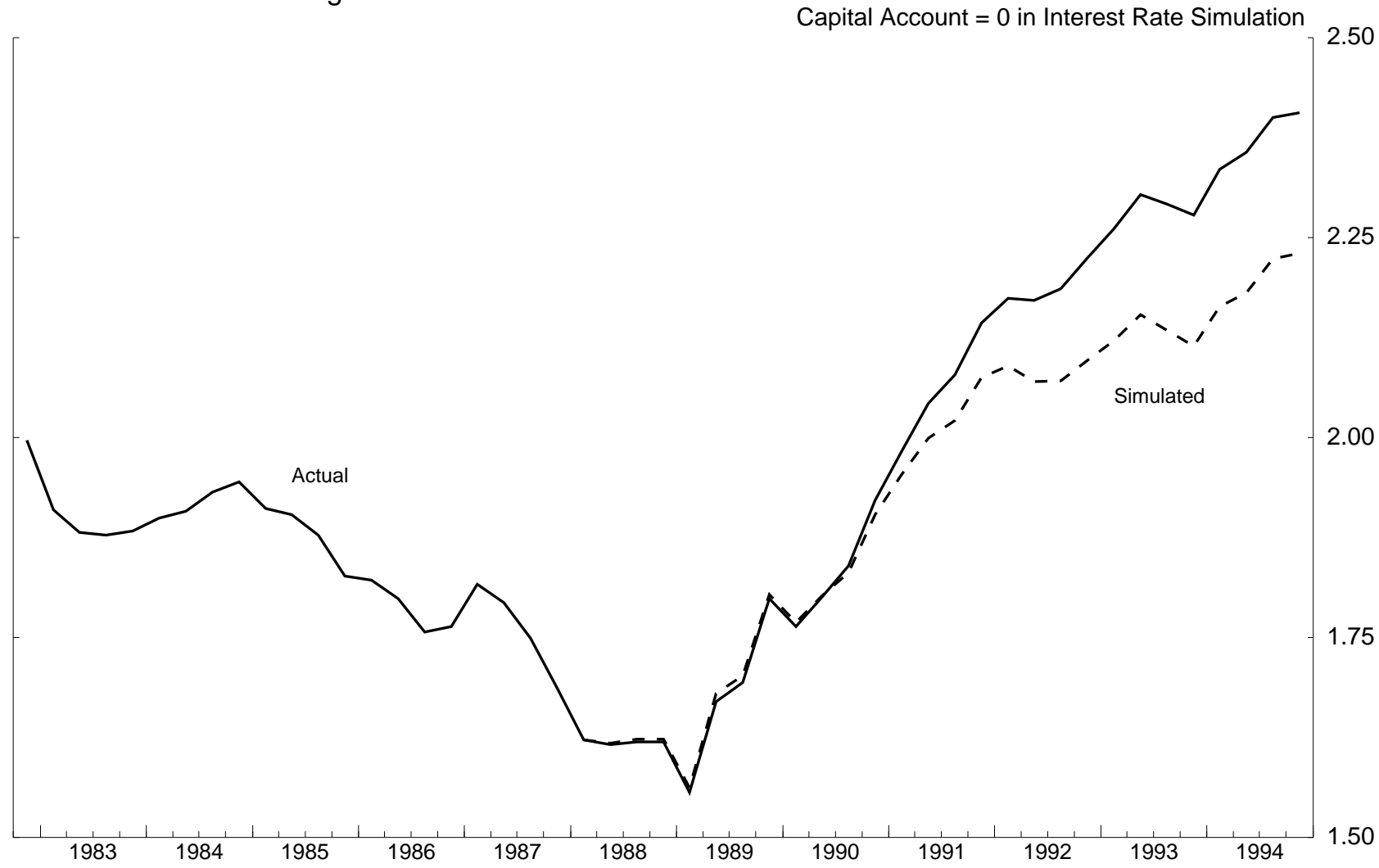

Actual and Simulated Log of Real M2

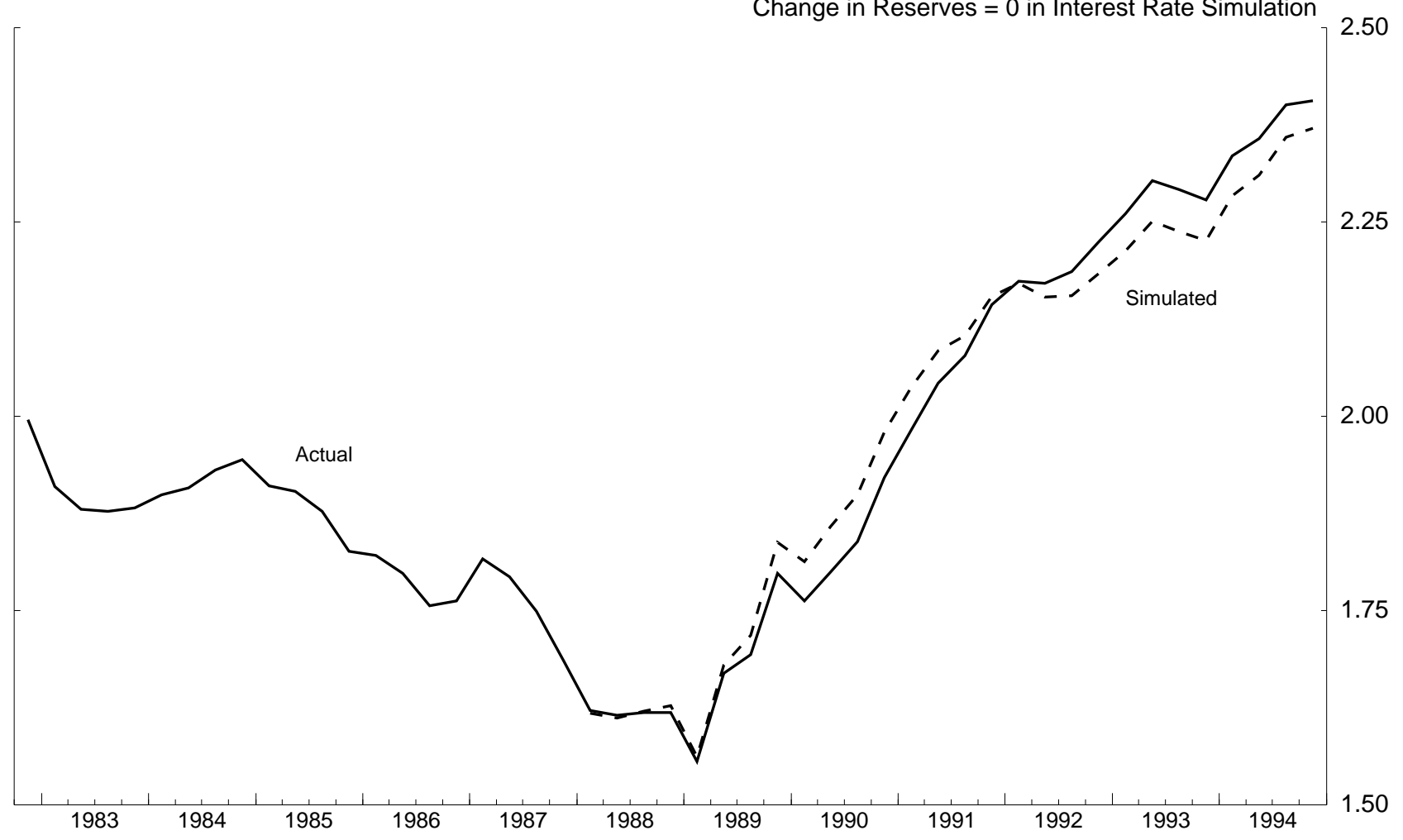




\section{Mexican Real M2 Simulations}

One-Equation Approach

Actual and Simulated Log of Real M2

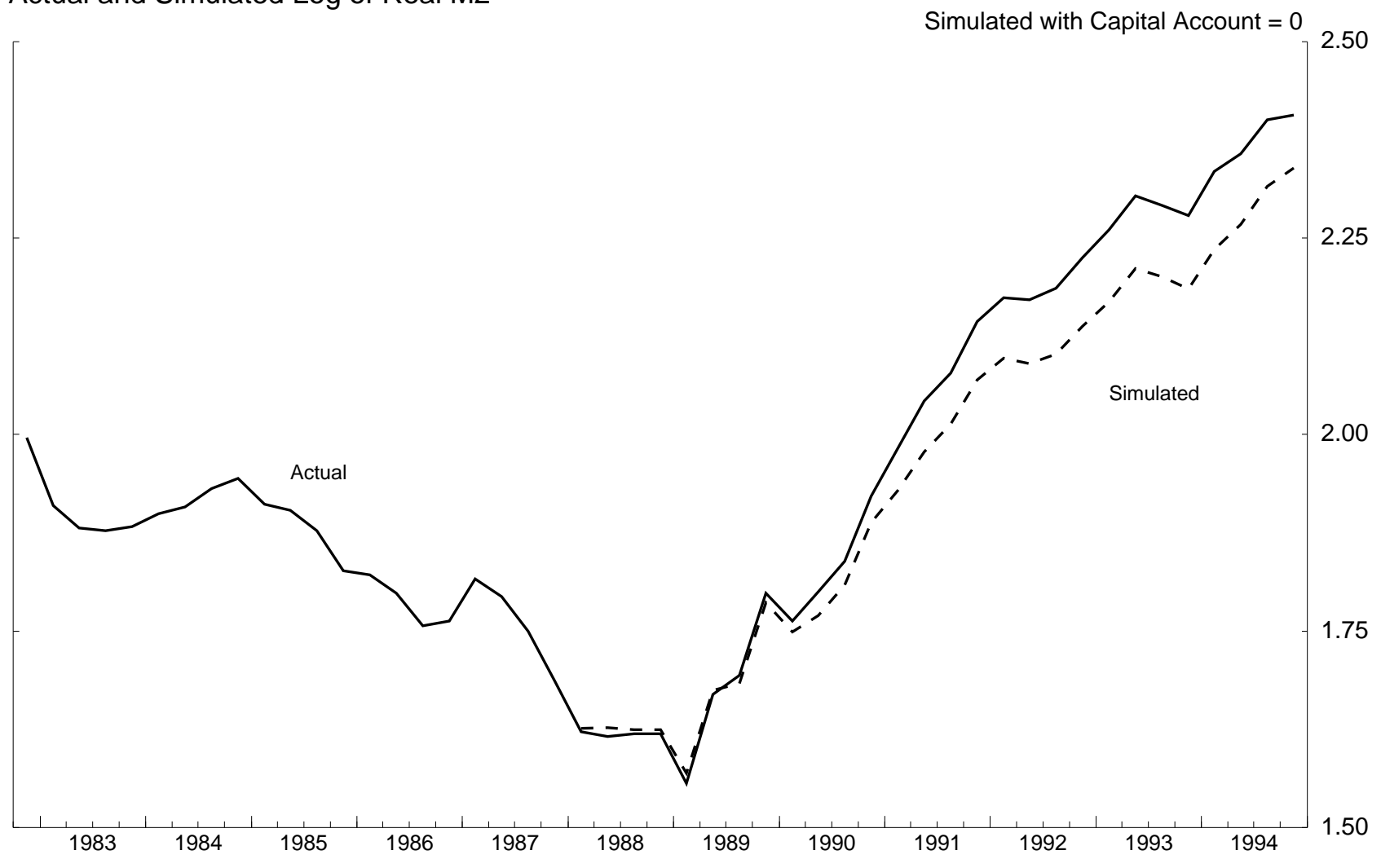

Actual and Simulated Log of Real M2

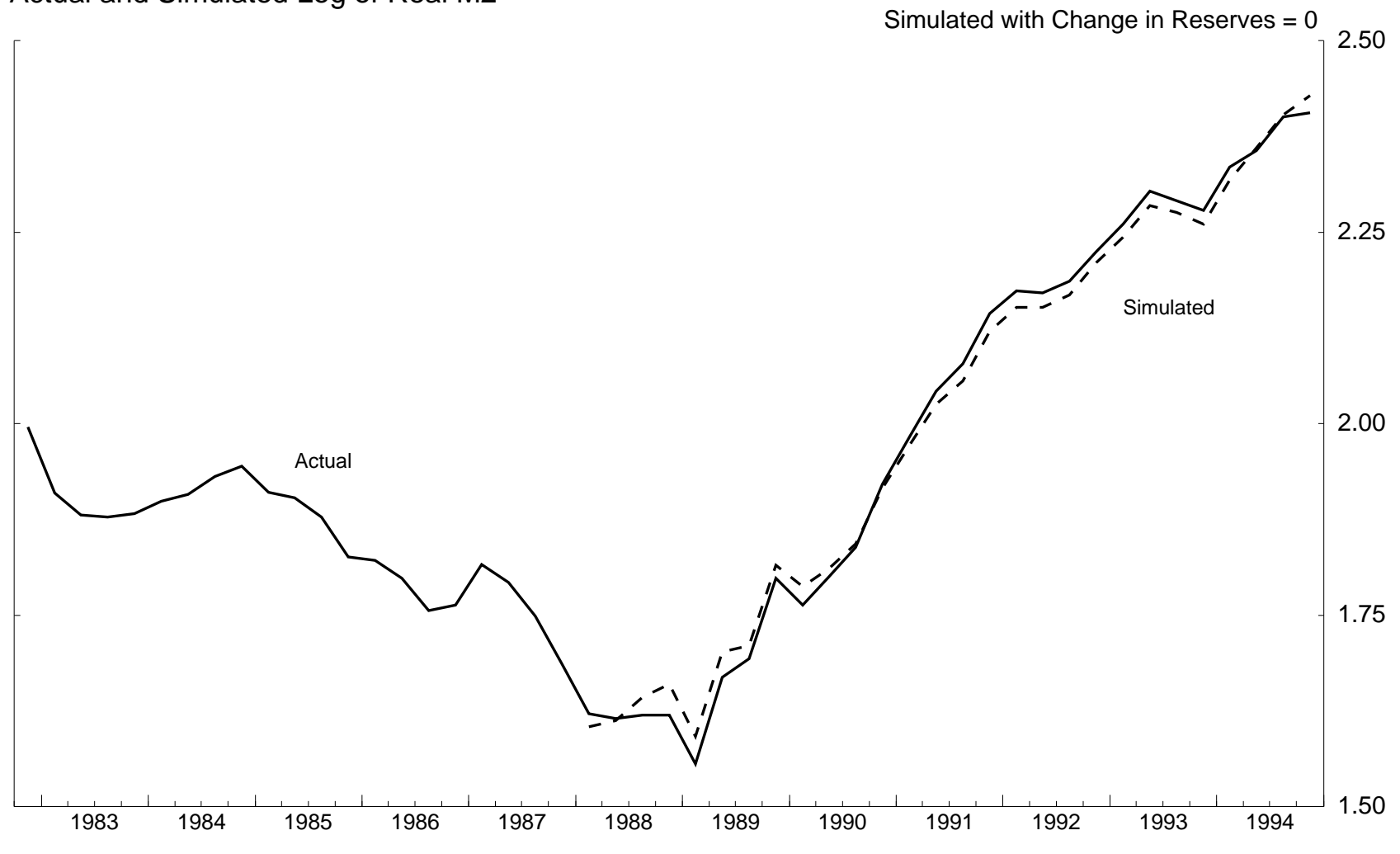




\section{Mexican Consumption Simulation}

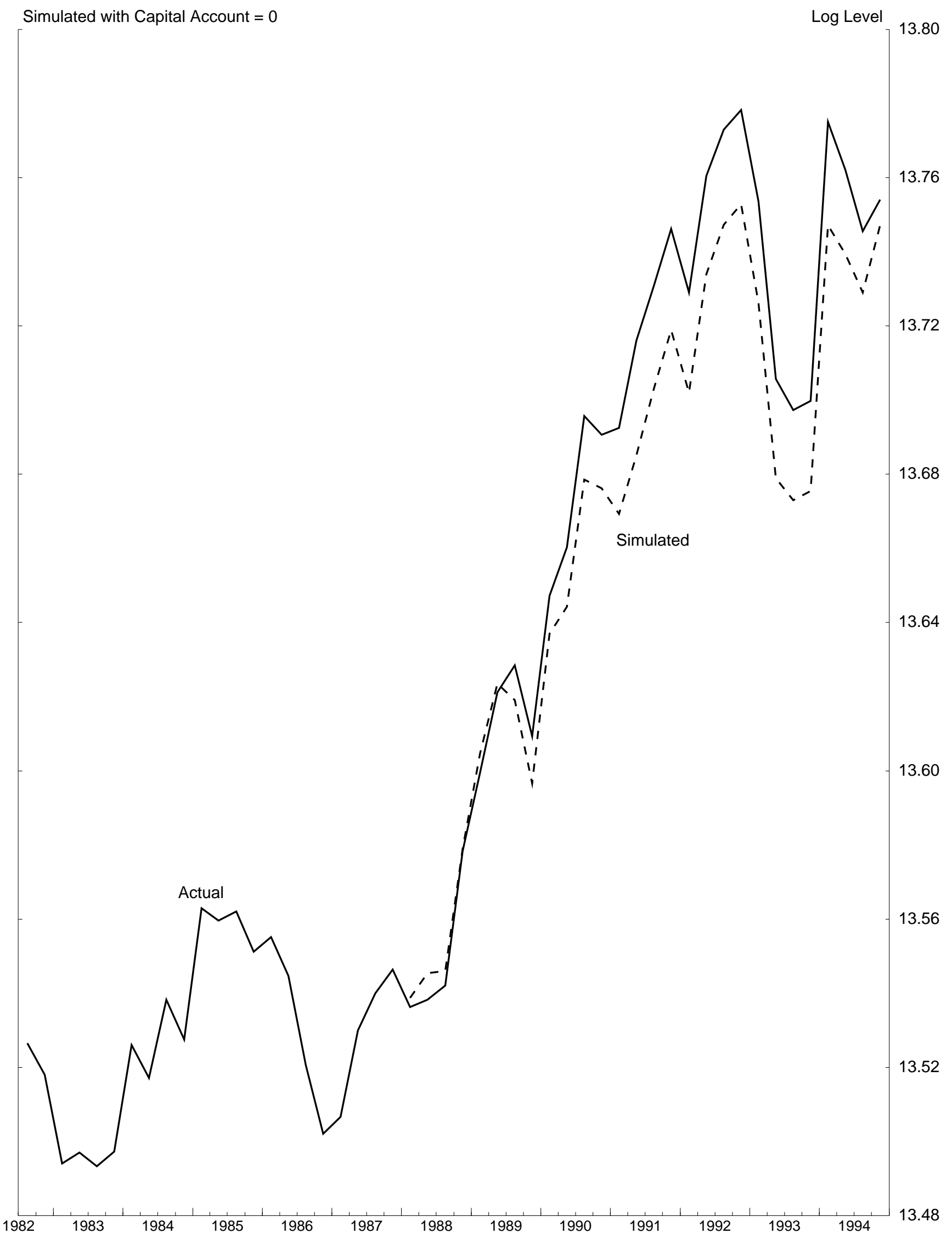




\section{Chart 5.1}

\section{Capital Flows - Latin America}

Solid - Capital Account; Dashed - FDI; Dotted - Portfolio Investment

Mexico

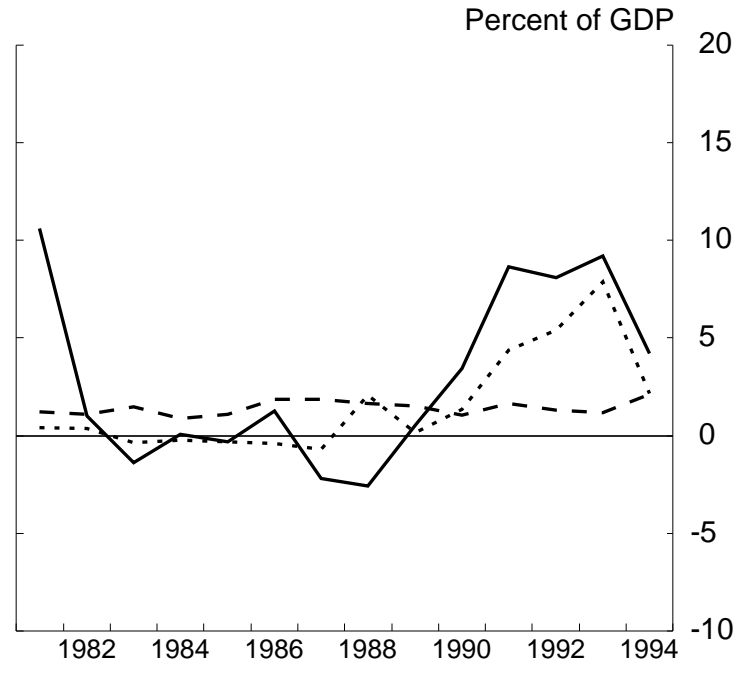

Brazil

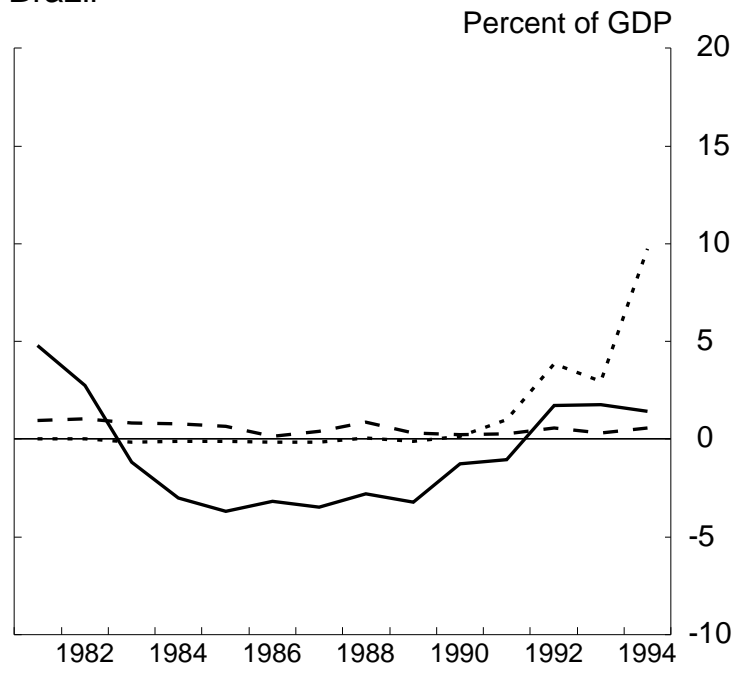

Argentina

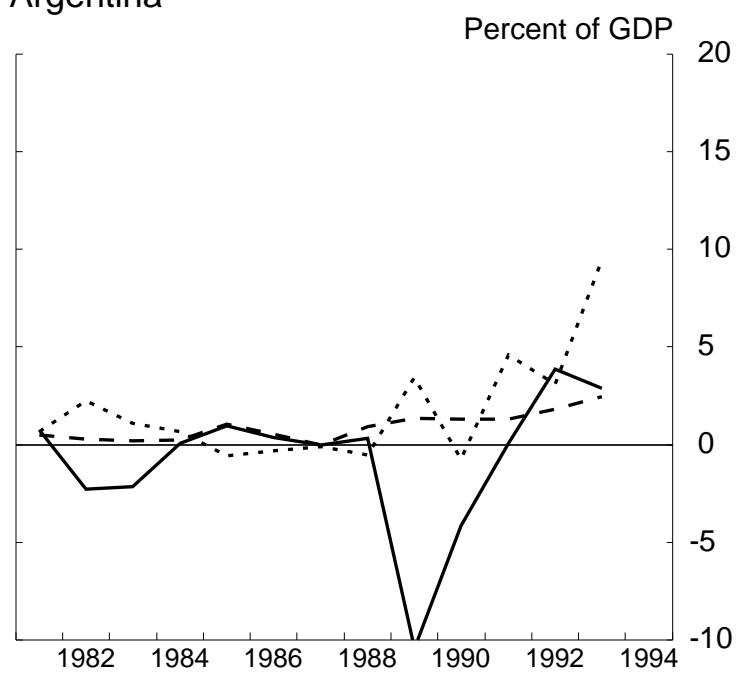

Colombia

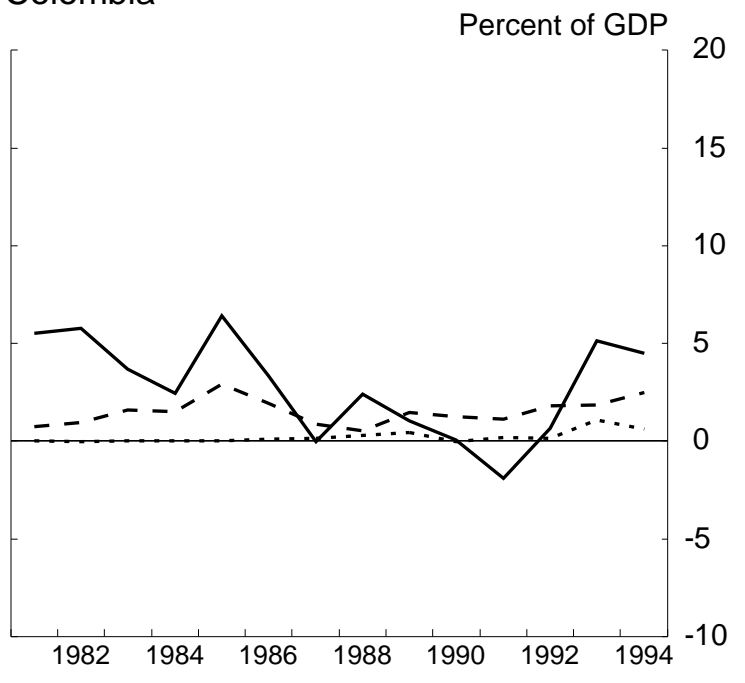

Chile

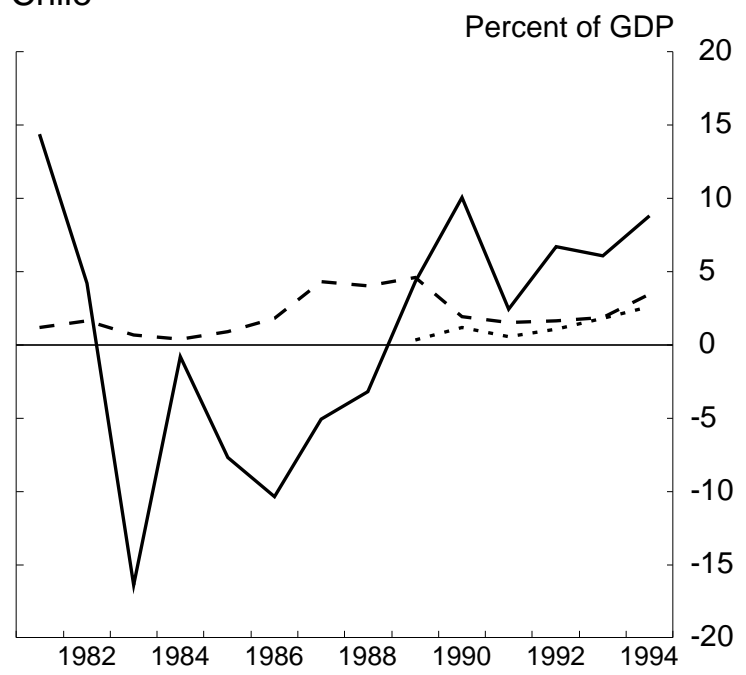




\section{Chart 5.2}

\section{Capital Flows - Asia}

Solid - Capital Account; Dashed - FDI; Dotted - Portfolio Investment

Thailand

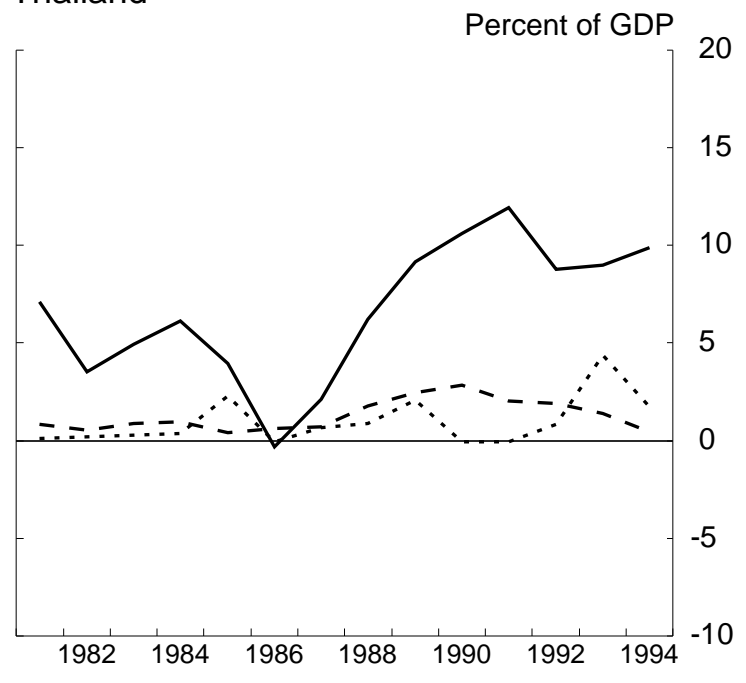

Philippines

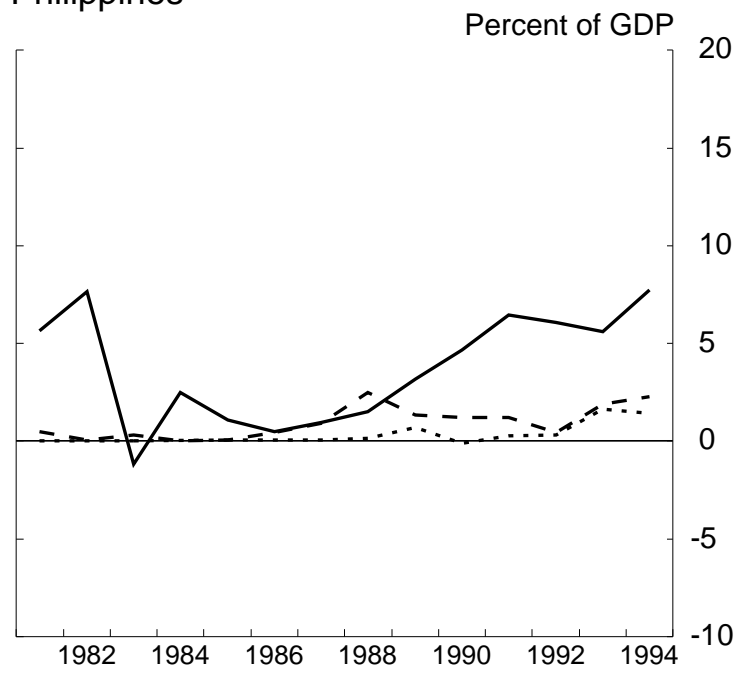

Malaysia

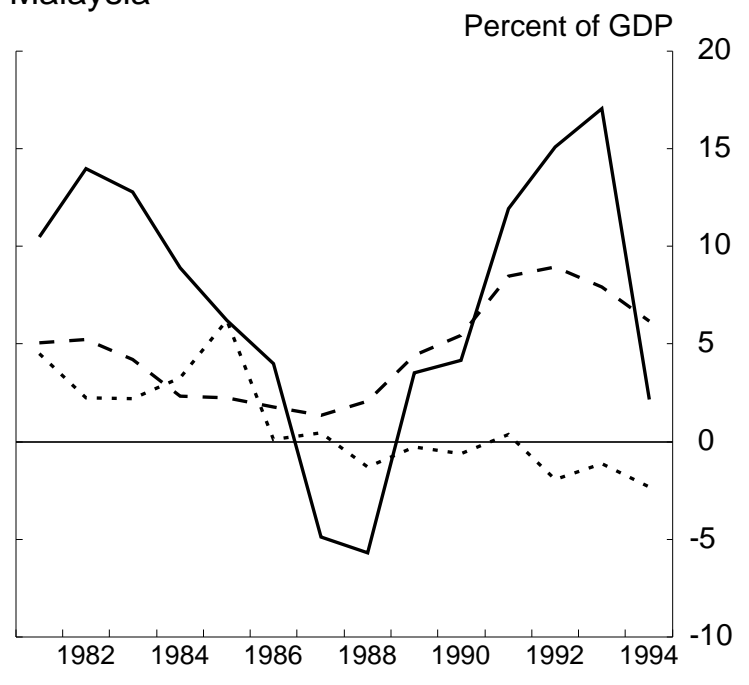

Indonesia

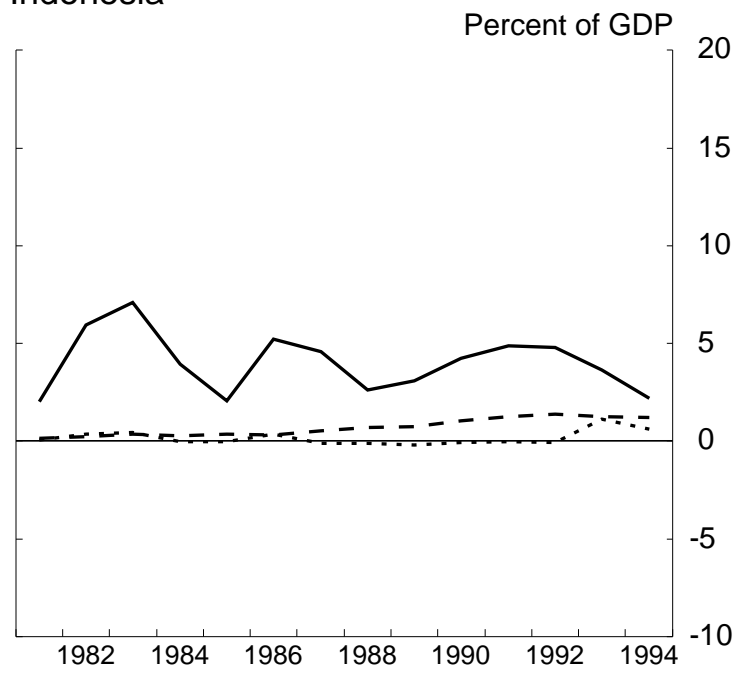

Korea

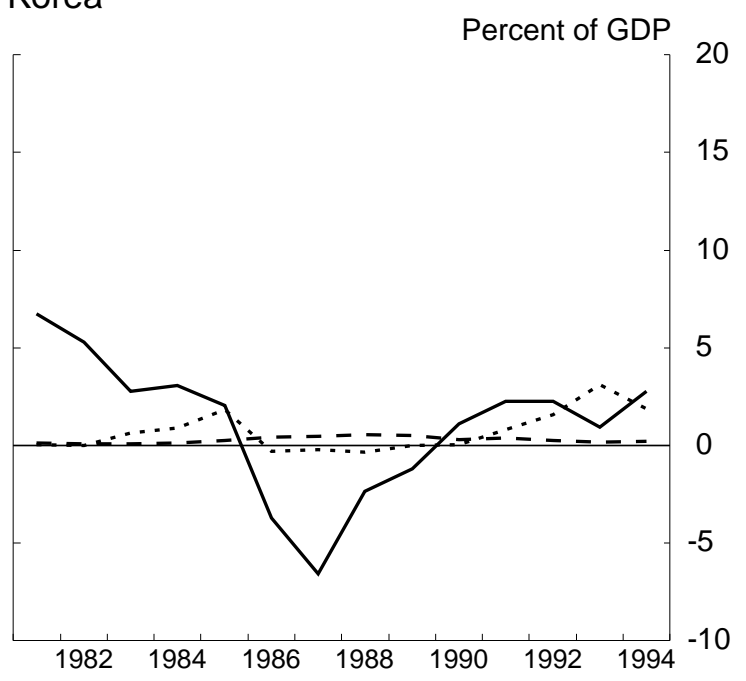




\section{Chart 5.3}

\section{Consumption Simulations - Latin America}

Solid - Actual, Dashed - Simulated with Capital Account $=0$

Mexico

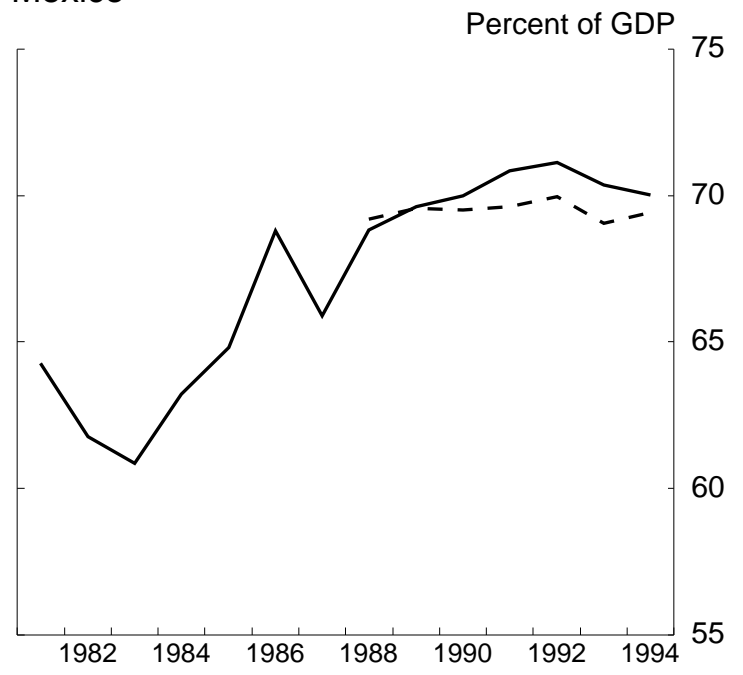

Brazil

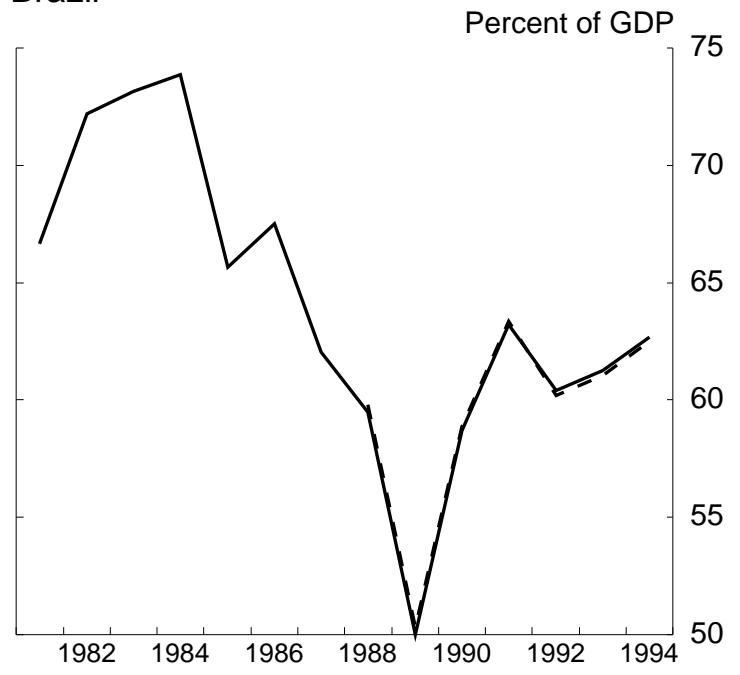

Argentina

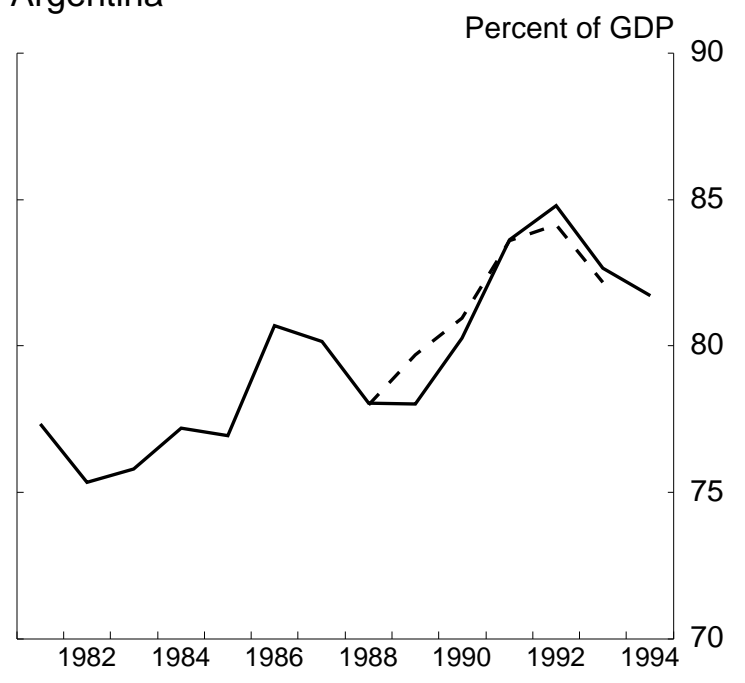

Chile

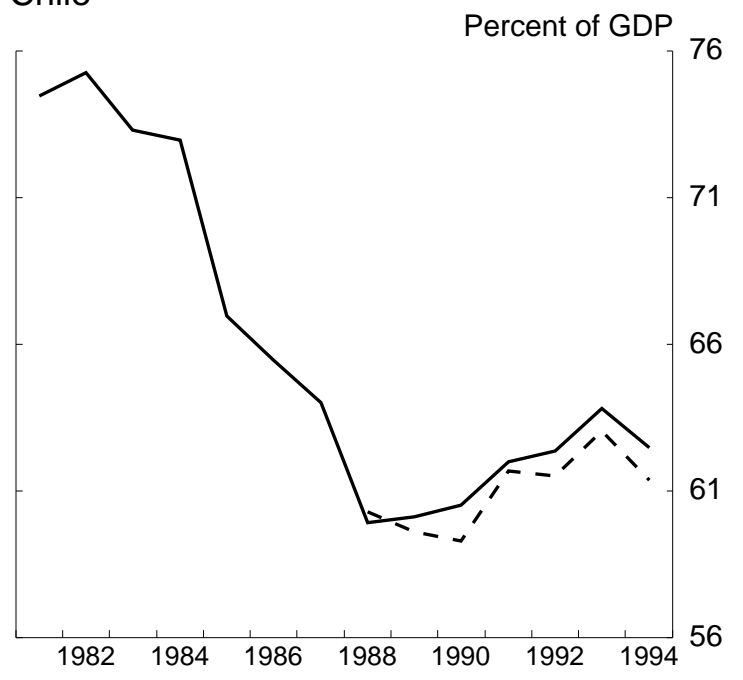

Colombia

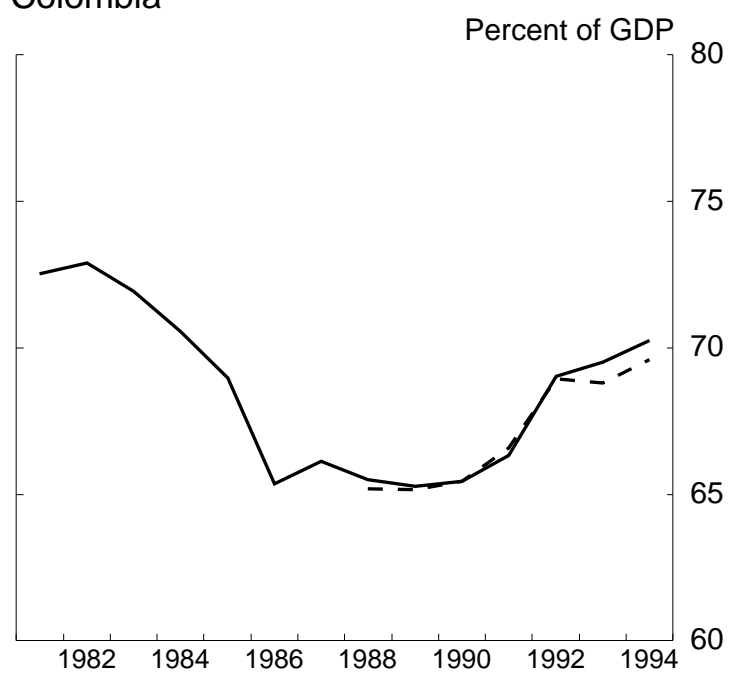


Chart 5.4

\section{Consumption Simulations - Asia}

Solid - Actual, Dashed - Simulated with Capital Account $=0$

Thailand

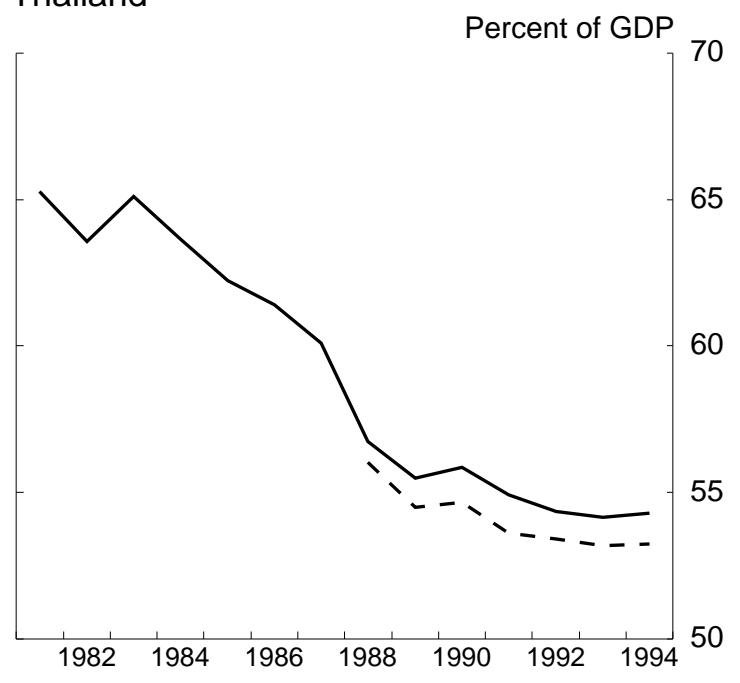

Philippines

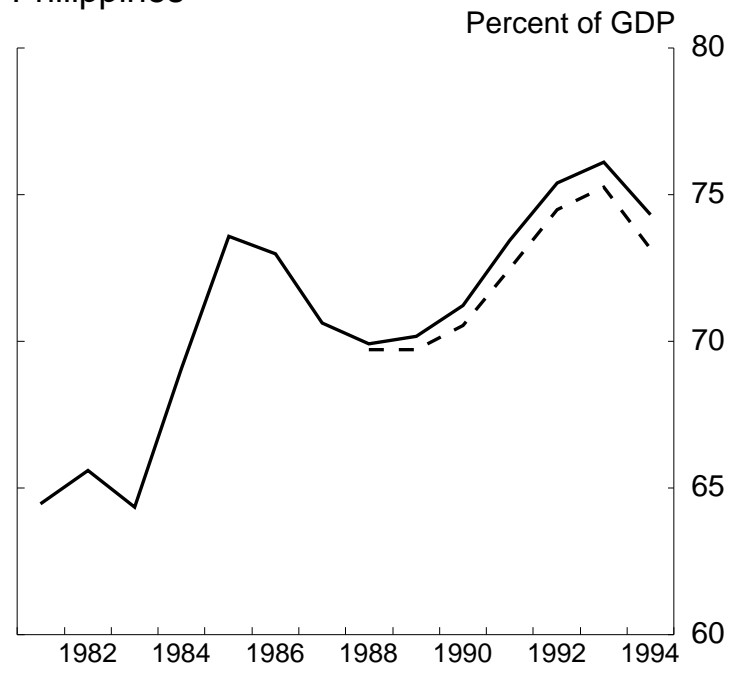

Malaysia

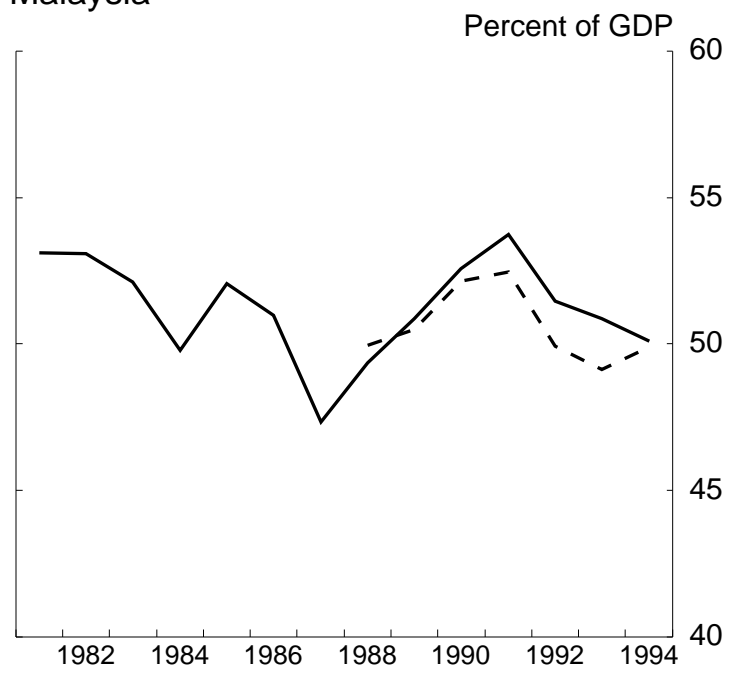

Indonesia

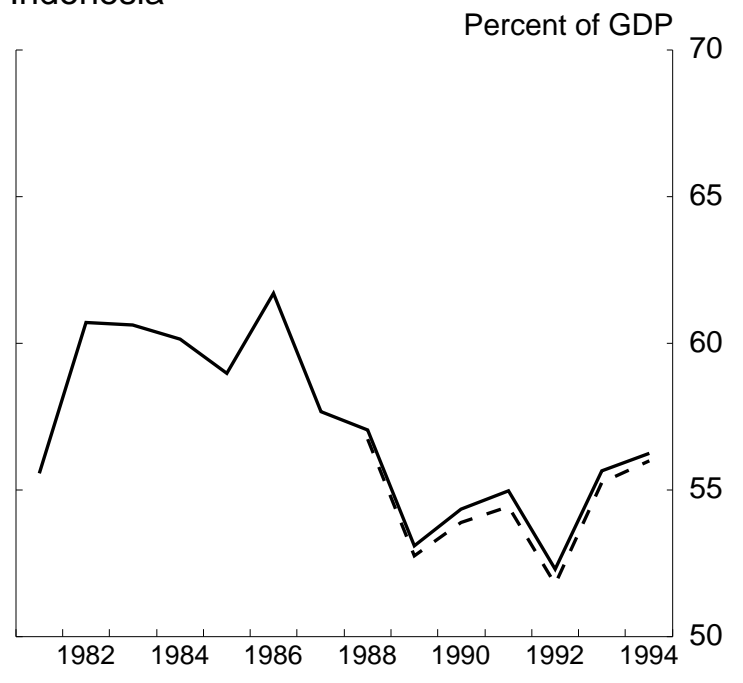

Korea

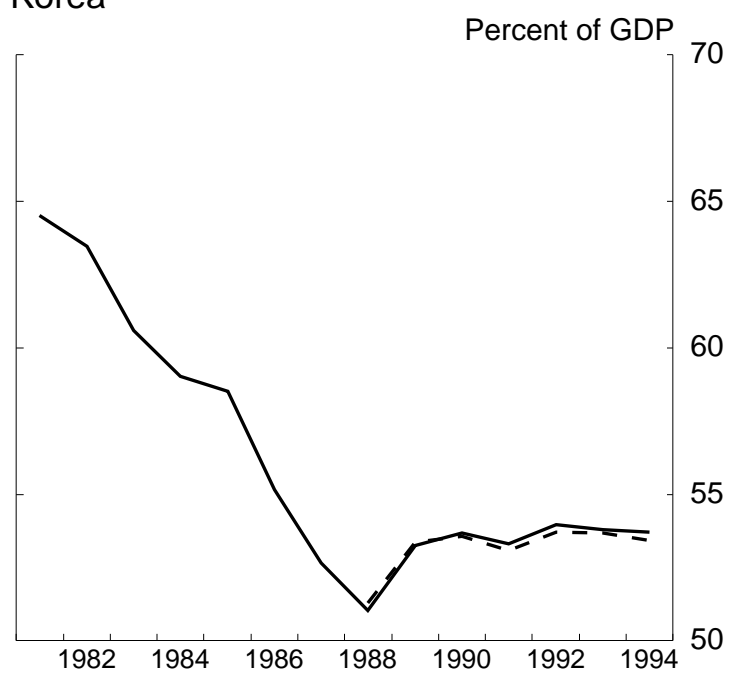




\section{Chart 5.5}

Investment Simulations - Latin America

Solid - Actual, Dashed - Simulated with Capital Account $=0$

Mexico

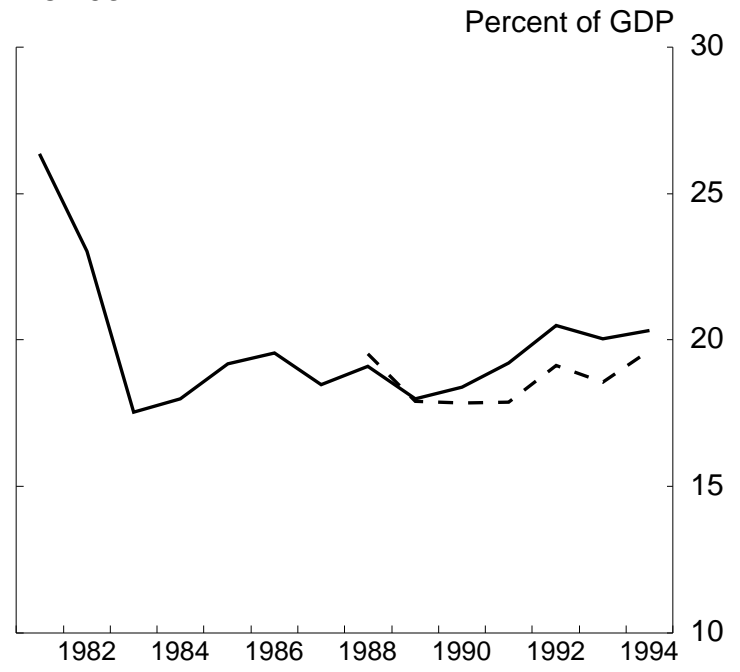

Brazil

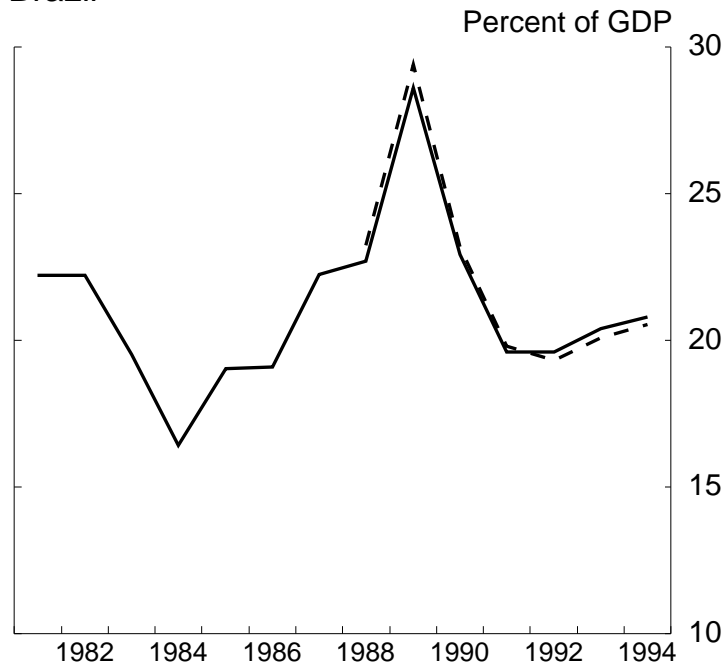

Colombia

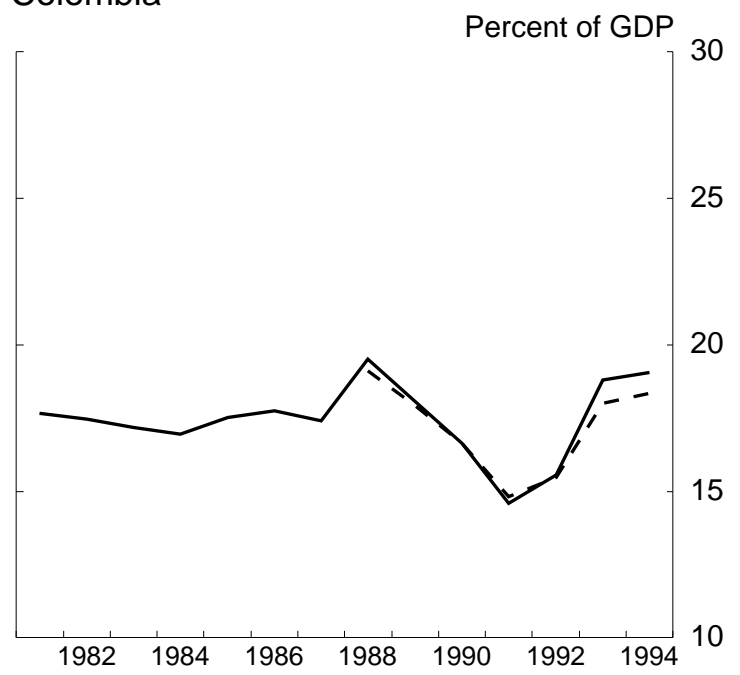

\section{Argentina}

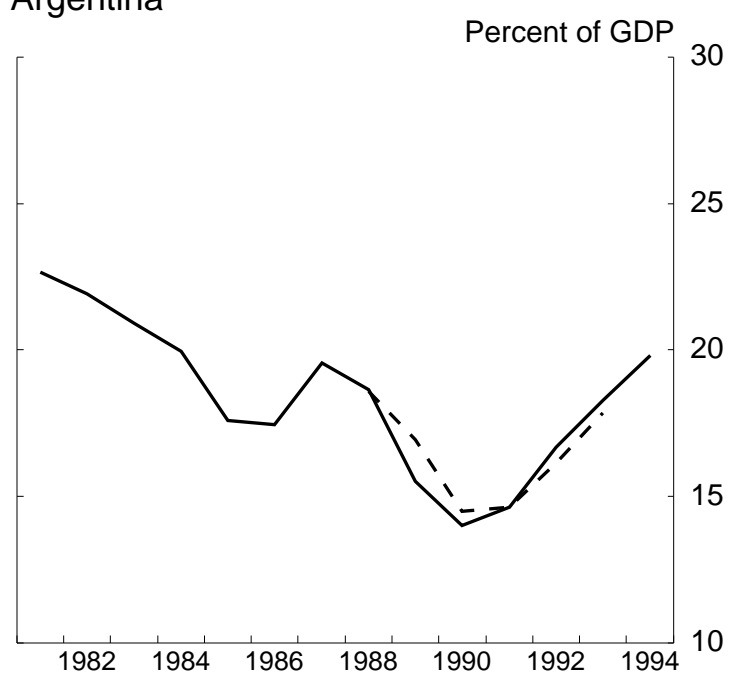

Chile

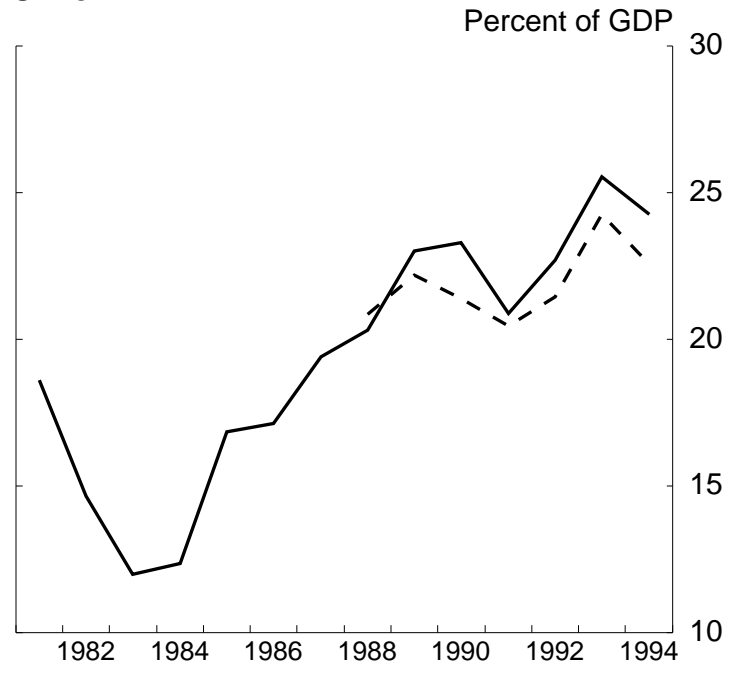




\section{Chart 5.6}

\section{Investment Simulations - Asia}

Solid - Actual, Dashed - Simulated with Capital Account $=0$

Thailand

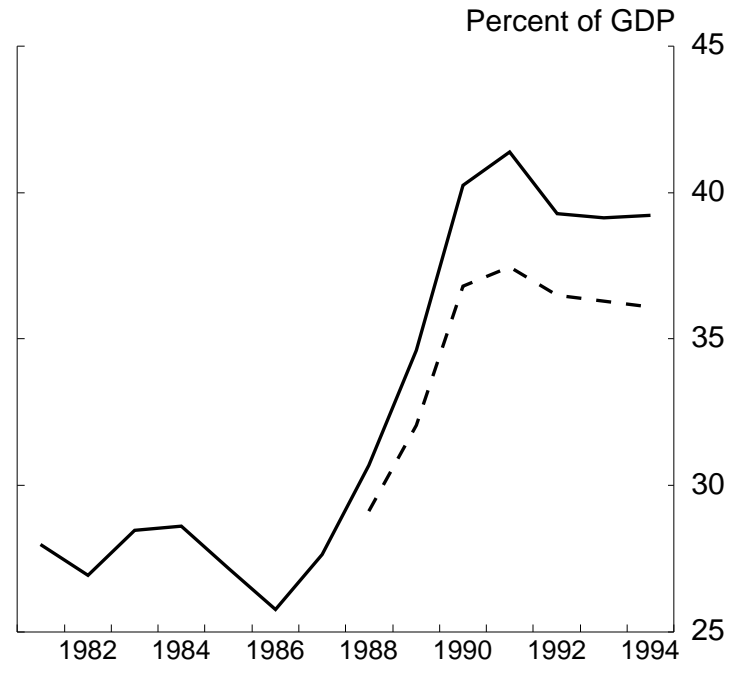

Philippines

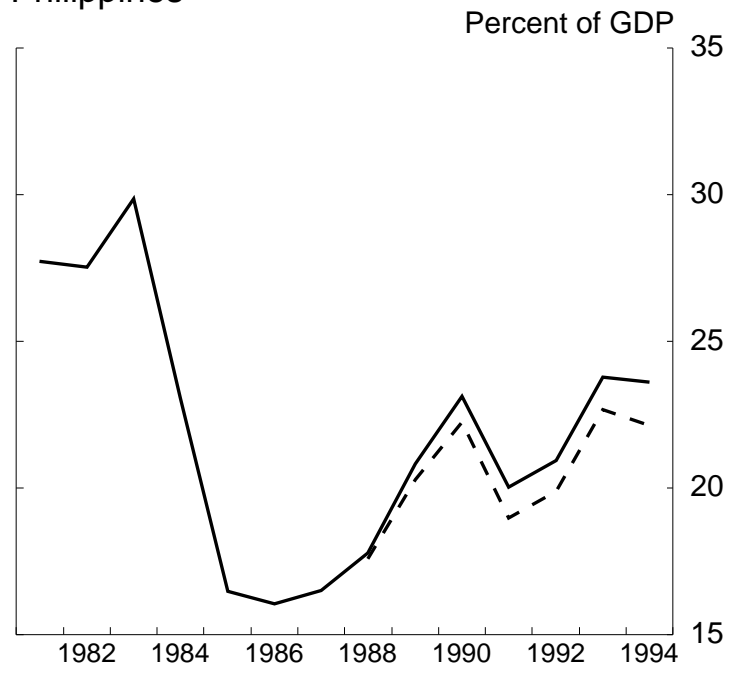

Korea

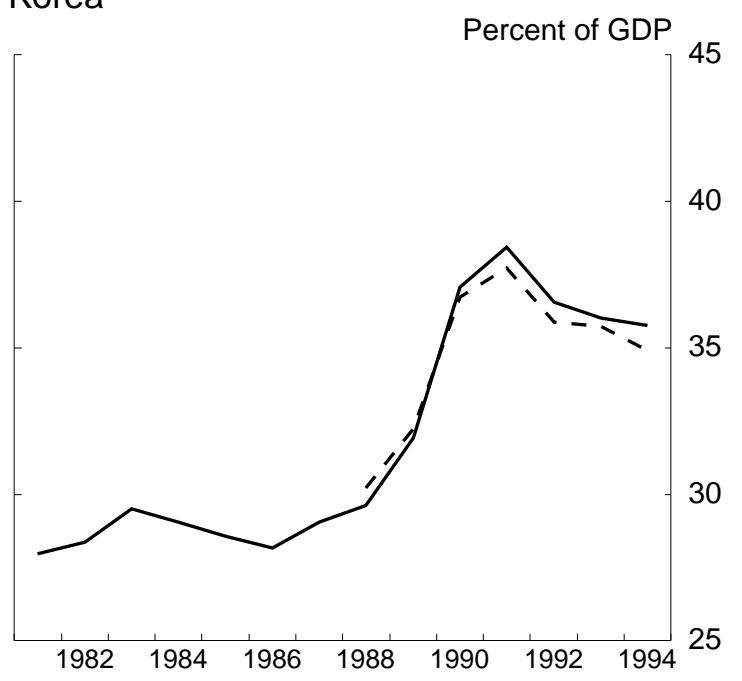

Malaysia

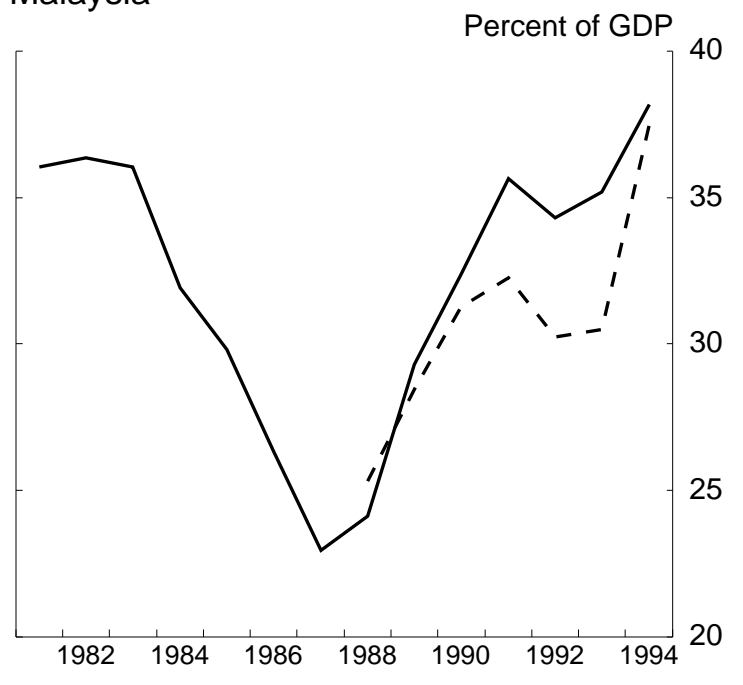

Indonesia

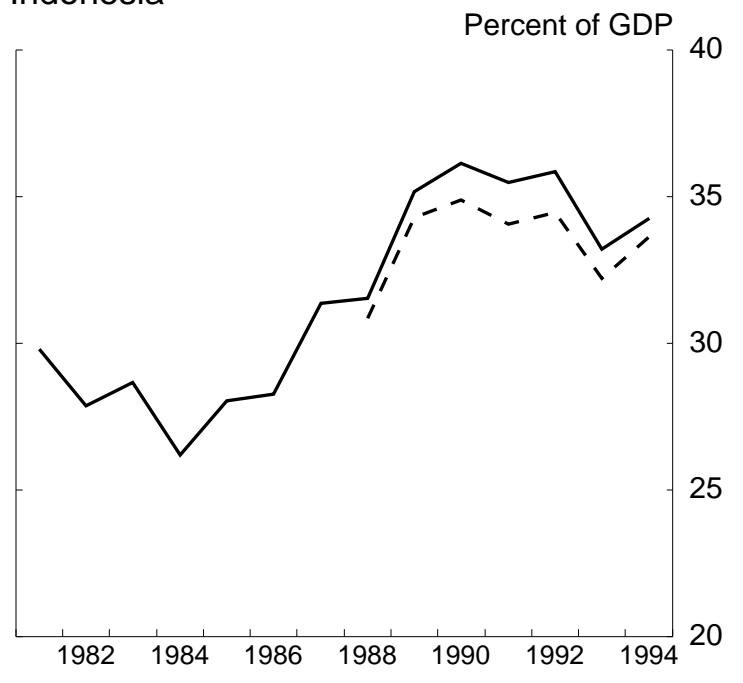

